\title{
Equity in Contemporary Immigration Enforcement: Defining Contributions and Countering Criminalization
}

\author{
Alia Al-Khatib \& Jayesh Rathod*
}

\section{INTRODUCTION}

During the 2016 Presidential election cycle, immigration policy emerged as a key campaign issue, with then-candidate Donald Trump promising a slate of restrictionist measures, including more aggressive immigration enforcement, curtailment of refugee admissions, and the construction of a wall along the U.S.-Mexico border. ${ }^{1}$ President Trump also infamously linked Mexican migrants with criminality, ${ }^{2}$ and elevated select narratives regarding the victims of violent crimes committed by noncitizens. ${ }^{3}$ His election, therefore, generated substantial concern among immigrant communities and their advocates, and fueled speculation regarding the fate of the approximately eleven million undocumented persons residing in the United States. ${ }^{4}$

* Alia Al-Khatib is a staff attorney at Justice at Work in Philadelphia, Pennsylvania. Jayesh Rathod is a Professor of Law at American University Washington College of Law (WCL). Thanks to Professor Lua K. Yuille for her invitation to participate in this symposium, and to Jamila Jefferson-Jones, Elizabeth Keyes, Kreig Kitts, Matthew Shaw, Anita Sinha, and Yolanda Vázquez for their feedback on earlier iterations of this project. WCL student Alexis Martinez provided helpful research assistance. Finally, sincere thanks to Meghan Harper and the Kansas Law Review for their careful and diligent editorial work.

1. David A. Graham, Has Trump Kept His Campaign Promises?, The AtLanTIC (Apr. 28, 2017), https://www.theatlantic.com/politics/archive/2017/04/trump-promises-cheat-sheet/507347/ (detailing various promises made by President Trump relating to immigration, and assessing the level of follow-through).

2. See Washington Post Staff, Full Text: Donald Trump Announces a Presidential Bid, WASH. PosT (June 16, 2015), https://www.washingtonpost.com/news/post-politics/wp/2015/06/16/full-textdonald-trump-announces-a-presidential-bid/?utm_term=.d9f75d3a4f2d ("When Mexico sends its people, they're not sending their best. . . They're bringing drugs. They're bringing crime. They're rapists. And some, I assume, are good people.").

3. See Becket Adams, Trump Gives Mic to Crime Victims of Illegal Immigrants, WASH. EXAMINER (Aug. 23, 2016, 11:00 PM), http://www.washingtonexaminer.com/trump-gives-mic-tocrime-victims-of-illegal-immigrants/article/2600044 (describing a then-candidate Donald Trump campaign rally in Austin, Texas that featured remarks from the family members of persons killed by unauthorized immigrants).

4. Jeffrey S. Passel \& D’Vera Cohn, 20 Metro Areas are Home to Six-in-ten Unauthorized 
The first year of the Trump presidency has understandably heightened anxiety among immigrants, given the steady trickle of immigration-related Executive Orders, along with an uptick in enforcement activity. ${ }^{5}$ While troubling to many, the administration's posture toward unauthorized migrants is the latest pendulum swing in federal immigration enforcement policy. The Reagan years saw the passage of the Immigration Reform and Control Act of 1986 (IRCA), which paired a broad legalization initiative with provisions that penalized employers who knowingly hired unauthorized workers. ${ }^{6}$ During the 1990 s, however, as the U.S. economy expanded and employers sought out low-wage migrant labor, enforcement of the IRCA's employer sanctions provisions was lax. ${ }^{7}$ It was during these years that the unauthorized migrant population in the United States grew substantially. ${ }^{8}$ The September 11, 2001 attacks led to a renewed focus on immigration enforcement and border control, with an emphasis on safeguarding national security. ${ }^{9}$ During the Obama years, immigration enforcement continued apace, ${ }^{10}$ while the executive branch promulgated measures that sought to insulate temporarily classes of noncitizens from removal. ${ }^{11}$ The approach has shifted once again under the Trump administration.

Immigrants in the U.S., PEW RES. CTR.: FACT TANK (Feb. 9, 2017), http://www.pewresearch.org/facttank/2017/02/09/us-metro-areas-unauthorized-immigrants/.

5. E.g., Enhancing Public Safety in the Interior of the United States, Exec. Order No. 13768, 82 Fed. Reg. 8799 (Jan. 25, 2017); see also ICE ERO Immigration Arrests Climb Nearly 40\%, U.S. IMMIGR. \& CUSTOMS ENF'T, https://www.ice.gov/features/100-days (last updated Nov. 2, 2017) (stating that interior immigration arrests increased by approximately $36 \%$ in the first four months of the Trump administration).

6. Betsy Cooper \& Kevin O'Neill, Lessons from the Immigration Reform and Control Act of 1986, 2005 Migration POL'Y INST. POL'Y BRIEF, at 2-3, http://www.migrationpoliy.org/pubs/ PolicyBrief_No3_Aug05.pdf.

7. Michael J. Wishnie, Prohibiting the Employment of Unauthorized Immigrants: The Experiment Fails, 2007 U. CHI. LEGAL F. 193, 209-11 (2007).

8. See Jens Manuel Krogstad, Jeffrey S. Passel \& D'Vera Cohn, 5 Facts About Illegal Immigration in the U.S., PEW RES. CTR.: FACT TANK (Apr. 27, 2017), http://www.pewresearch.org/ fact-tank/2017/04/27/5-facts-about-illegal-immigration-in-the-u-s/ (illustrating the precipitous growth in the undocumented population in the United States during the 1990s).

9. See generally Deepa Iyer \& Jayesh M. Rathod, 9/11 and the Transformation of U.S. Immigration Law and Policy, HUM. RTS., Winter 2011, at 10 (describing the transformations of and emphasis placed on U.S. immigration law and policy following September 11, 2011, including specific changes pertaining to controlling entry into the United States, new emphasis on national origins and past affiliations, and increased detention and deportation).

10. Muzaffar Chishti, Sarah Pierce, \& Jessica Bolter, The Obama Record on Deportations: Deporter in Chief or Not?, MigRATION POL'Y INST. (Jan. 26, 2017), https://www.migrationpolicy.org/article/obama-record-deportations-deporter-chief-or-not (presenting data showing an increase in overall removals during the Obama years, guided by specific removal priorities).

11. See Memorandum from Janet Napolitano, Sec'y of Homeland Sec., to David V. Aguilar, Acting Comm'r, U.S. Customs \& Border Prot., Alejandro Mayorkas, Dir., U.S. Citizenship \& 
Over these same decades, as the appetite for enforcement has waxed and waned, immigration-criminal intersections have solidified and grown in salience. In the 1990s, the passage of various federal laws significantly expanded crime-based removal grounds, and placed large swaths of noncitizens-including long-term permanent residents-at risk of removal. ${ }^{12}$ The U.S. government has also aggressively pursued federal criminal prosecutions for illegal entry or re-entry into the United States, generating a proliferation of these cases on federal criminal dockets. ${ }^{13}$ Additionally, the federal government has sought to strengthen its ties with local law enforcement in order to identify and detain removable noncitizens who interface with state and local police. ${ }^{14}$ The merger of the criminal and immigration systems is evident in the growth of immigration detention in the United States, with tens of thousands of individuals held for civil violations in conditions that closely resemble prisons and jails. ${ }^{15}$ These various structures of criminalization have spawned advocacy and research focused on the burgeoning "crimmigration" crisis. ${ }^{16}$

Immigration Servs., \& John Morton, Dir., U.S. Immigration \& Customs Enf't, on Exercising Prosecutorial Discretion with Respect to Individuals Who Came to The United States as Children (June 15, 2012), http://www.dhs.gov/xlibrary/assets/s1-exercising-prosecutorial-discretionindividuals-who-came-to-us-as-children.pdf (announcing, formally, the Deferred Action for Childhood Arrivals (DACA) program).

12. See Angela M. Banks, Proportional Deportation, 55 WAYNe L. REV. 1651, 1661 (2009) (noting that the Antiterrorism and Effective Death Penalty Act of 1996 and the Illegal Immigration Reform and Immigrant Responsibility Act of 1996 "dramatically increased the types of criminal activity that made noncitizens deportable and made these deportation grounds retroactive").

13. See, e.g., Immigration Now 52 Percent of all Federal Prosecutions, TRAC REPORTS (Nov. 28, 2016), http://trac.syr.edu/tracreports/crim/446/ ("Immigration remains the major focus of federal criminal enforcement efforts.").

14. Two programs that facilitate federal-state cooperation are the $287(\mathrm{~g})$ program and Secure Communities. The former derives from authority in Section $287(\mathrm{~g})$ of the Immigration and Nationality Act and allows local law enforcement agencies to enter into agreements with U.S. Immigration and Customs Enforcement (ICE), whereby local officers are trained and then permitted to perform specific immigration enforcement functions. See Delegation of Immigration Authority Section 287(g) Immigration and Nationality Act, U.S. IMMIGR. \& CUSTOMS ENF'T, https://www.ice.gov/287g (last updated Mar. 26, 2018). Secure Communities is a database-sharing initiative that permits ICE to review information (including biometrics data) regarding individuals who come into contact with local law enforcement agencies, allowing ICE to identify and take into custody potentially removable noncitizens. See Secure Communities, U.S. IMMIGR. \& CUSTOMS ENF’T, https://www.ice.gov/securecommunities (last updated Mar. 20, 2018). While both programs were phased out under the Obama administration, the current administration recommitted to these programs and encouraged the expansion of 287(g) agreements to new jurisdictions. Enhancing Public Safety in the Interior of the United States, Exec. Order No. 13768, 82 Fed. Reg. 8799 (Jan. 25, 2017).

15. Anita Sinha, Arbitrary Detention? The Immigration Detention Bed Quota, 12 DuKE J. CONST. L. \& PUB. POL'Y 77, 81-83 (2017).

16. See Juliet Stumpf, The Crimmigration Crisis: Immigrants, Crime, and Sovereign Power, 56 AM. U. L. REV. 367, 376 (2006) (defining "crimmigration" as "criminalization of immigration law"). 
Consistent with the expansion of crimmigration law, the Trump administration has signaled a strong focus on immigration enforcement, and in support of this stance, has consistently invoked the rhetoric of immigrant criminality. ${ }^{17}$ Although precise answers regarding enforcement policies are elusive, a January 25, 2017 executive order on interior immigration enforcement provides a blueprint of the administration's approach. ${ }^{18}$ The order notes that noncitizens who enter illegally, overstay visas, or violate visa terms "present a significant threat to national security and public safety" - particularly those "who engage in criminal conduct in the United States." 19 With respect to removal priorities, the order asserts that the faithful execution of immigration laws cannot occur "if we exempt classes or categories of removable aliens from potential enforcement." 20 Accordingly, Section 5 of the order articulates a rather broad list of removal priorities. ${ }^{21}$ In addition to those noncitizens who are removable based on criminal or national security grounds, the order prioritizes other "removable aliens" who "have been convicted of any criminal offense," as well as those with pending criminal charges or those who have "committed acts that constitute a chargeable criminal offense." 22 In practice, this means that someone who is in the United States without legal status (and thus removable) will be prioritized for expulsion simply because of pending criminal charges or suspected criminal activity. In short, under the current administration, even the slightest hint of association with criminal behavior renders one a priority for removal, and class-based exceptions are discouraged. By adopting this approach, the Trump administration has largely jettisoned the prosecutorial discretion initiatives cultivated during the Obama years. ${ }^{23}$

17. See, e.g., Vivian Yee, Thousands of Federal Inmates are in U.S. Illegally, Administration Says, N.Y. TIMES (Dec. 21, 2017), https://www.nytimes.com/2017/12/21/us/undocumentedimmigrants-crimes.html (citing a statement by Attorney General Sessions regarding unauthorized immigrants, criminality, and public safety).

18. Enhancing Public Safety in the Interior of the United States, 82 Fed. Reg. 8799.

19. Id. at 8799 .

20. See id.

21. Id. at 8800 .

22. Id. One question that remains unanswered is whether ICE considers someone who entered without inspection to have "committed a chargeable criminal offense." Though entry without inspection is often treated as a civil immigration law violation, it is also codified in the U.S. Code as a criminal misdemeanor. See 8 U.S.C. § 1325 (2012) (“Improper entry by alien").

23. See generally Shoba Sivaprasad Wadhia, The History of Prosecutorial Discretion in Immigration Law, 64 AM. U. L. REV. 1285 (2015) (describing the historical role that prosecutorial discretion has played in immigration law and detailing its application to select executive actions during the Obama administration). Along these lines, the enforcement priorities laid out by the Obama administration in November 2014 were premised on actual, not potential, criminal convictions and focused on a narrower subset of criminal conduct. Memorandum from Dep't of Homeland Sec. Sec'y, 
Although the current administration has signaled a "no exceptions" approach to enforcement, the exercise of discretion is essential for the sustainability of any administrative structure, including the U.S. immigration system. ${ }^{24}$ Perhaps most important, the absence of any discretion at the margins will compromise a system's moral legitimacy. ${ }^{25}$ Indeed, discretion is necessary to inject some fairness into the immigration system and to allow for consideration of factors that are otherwise irrelevant to the application of harsh removal grounds. ${ }^{26}$ Practical considerations also compel discretion: even if the federal government hoped to remove all persons present in the United States without authorization, there simply are not enough enforcement resources to accomplish that goal. ${ }^{27}$ Given these factors, the executive branch will have to continue priority-setting, notwithstanding the restrictionist, unforgiving rhetoric propagated by President Trump and other senior administration officials. These enforcement priorities undoubtedly will be shaped by policies and attitudes regarding crime-related conduct.

In this context of amorphous priorities and entrenched structures of criminalization, this article re-engages with a critical question: what kinds of equities should insulate a noncitizen residing in the United States from removal, notwithstanding their unlawful entry and/or other basis for removability? This article draws upon equity theory and related theories of membership and offers a set of principles to help guide priority-setting in immigration enforcement. Building upon prior scholarship, it seeks to

Jeh Charles Johnson to Thomas S. Winkowski, Acting Dir., U.S. Immigration \& Customs Enf't, R. Gil. Kerlikowske, Comm'r, U.S. Customs and Border Prot., Leon Rodriguez, Dir., U.S. Citizenship \& Immigration Servs., Alan D. Bersin, Acting Assistant Sec'y for Policy, on Policies for the Apprehension, Detention, and Removal of Undocumented Migrants (Nov. 20, 2014), http://www.dhs.gov/sites/default/files/publications/14_1120_memo_prosecutorial_discretion.pdf.

24. See Daniel Kanstroom, Smart(er) Enforcement: Rethinking Removal, Structuring Proportionality, and Imagining Gradated Sanctions, 30 J. L. \& PoL. 465, 482-83 (2015) (describing how discretion and proportionality have shaped immigration enforcement in the United States).

25. See Jason A. Cade, Enforcing Immigration Equity, 84 FordHAM L. REV. 661, 664 (2015) (“Any normatively justifiable deportation system requires equity."); Zachary S. Price, Enforcement Discretion and Executive Duty, 67 VAND. L. REV. 671, 703 (2014) ("[T] he deep historic roots of the modern intuition that some degree of discretion in enforcement is essential to the just operation of criminal justice and the administrative state.").

26. Cade, supra note 25, at 664-65.

27. See id. at 664 . A recent study found that removing all undocumented immigrants would take twenty years, would cost the government between $\$ 400$ and $\$ 600$ billion dollars, and would require a dramatic expansion in enforcement personnel and related infrastructure. BEN GITIS, THE PERSONNEL

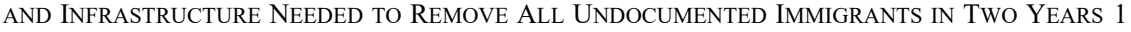
(Am. Action Forum, Feb. 2016), https://www.americanactionforum.org/wpcontent/uploads/2016/03/2016_Immigration_Update.pdf. But even the process of hiring additional immigration agents may face bureaucratic hurdles. See Michael D. Shear \& Ron Nixon, Constraints Threaten Trump's Promise of an Immigration Crackdown, N.Y. TIMES (Feb. 17, 2017), https://www.nytimes.com/2017/02/17/us/politics/national-guard-illegal-immigrants-report.html. 
articulate with more precision the type of contributions by noncitizens that should matter. ${ }^{28}$ Having outlined a typology of contributions, this article engages with a second key inquiry: How should those contributions be weighed vis-à-vis criminal conduct, including conduct closely related to the contribution itself? The theoretical framework offered by this article does not resolve all decisions relating to immigration enforcement, but it provides a more nuanced understanding of immigrant contributions, along with suggestions for how to assess the forms of criminalization that may be operating in a given case.

The remainder of this article proceeds as follows. Part II describes the shrinking space for equity in immigration enforcement, and the need to distill the types of contributions that should insulate noncitizens from removal. In so doing, this section catalogs the kinds of contributions mentioned in existing or previous immigration laws and policies. Part II concludes by describing a set of theories that support undocumented noncitizens' claims to remain in the United States, given their contributions and connections to U.S. society. Part III of this article offers simple typology of contributions that should matter in the context of immigration enforcement decisions. This section delves deeper into how some of these selfsame contributions are nullified by various types of criminalization, including the invocation by the government of unlawful activity related, in some way, to the positive contribution. We seek to untangle these various threads and offer fairer principles by which to measure immigrant contributions. The article concludes, in Part IV, with an analysis of some of the limitations of our approach.

\section{EQUITABLE CONSIDERATIONS AND SUPPORTING THEORIES}

This section describes how the discretion of officers and judges in the immigration system has been curtailed by the creeping influence of criminalization, as reflected in mandatory bars and other obstacles to relief. One under-theorized aspect of discretionary decision-making is the weight that should be accorded to contributions made by noncitizens. This section briefly catalogs the types of contributions that have been named in laws and agency memoranda, and outlines the theoretical justifications for an emphasis on noncitizen contributions.

28. As this article focuses on noncitizens' contributions, the analysis and recommendations presented herein apply primarily to persons who have resided in the U.S. for some period of time. Accordingly, the article does not address priority-setting for recent arrivals, such as asylum seekers. 


\section{A. Creating Space for Equitable Considerations}

Laws enacted in recent decades have constricted decision-makers' ability to consider favorable factors, or "positive equities" in immigration parlance, in the context of enforcement decisions and removal proceedings. For example, mandatory bars linked to criminal activity have rendered many noncitizens ineligible for immigration relief. In particular, the "aggravated felony" category of crimes operates as a bar to many commonly asserted forms of relief. ${ }^{29}$ Other categories, such as "particularly serious crime" and "significant misdemeanor," likewise foreclose options for protection. ${ }^{30}$ Laws have also limited judges' ability to revisit custody decisions by mandating detention for a broad spectrum of noncitizens in removal proceedings. ${ }^{31}$ Because of these laws, decisionmakers are simply unable to consider the positive equities in many noncitizens' cases, including the types of contributions they have made during their time in the United States.

The operation of these existing laws generates staggering inequities, as even noncitizens with strong ties and permanent residence in the United States remain vulnerable to deportation. For example, a long-term permanent resident with significant connections to the United States can be labeled as an "aggravated felon" for comparatively minor conduct, and thus will face likely removal from the United States. ${ }^{32}$ One common scenario involves a noncitizen who is convicted for a minor shoplifting offense and receives a twelve-month suspended sentence. Under current law, such a crime could be classified as an aggravated felony theft offense. ${ }^{33}$ Similarly, a permanent resident can be held in mandatory

29. 8 U.S.C. §§ 1101(a)(43) (2012 \& Supp. 2016), 1227(a)(2)(A)(iii) (2012).

30. A noncitizen who has been convicted of a "particularly serious crime" is typically ineligible for two common forms of fear-based relief: asylum and withholding of removal. 8 U.S.C. $\S \S$ 1158(b)(2)(A)(ii), 1231(b)(3)(B)(ii) (2012). The "significant misdemeanor" category of crimes is a relatively new category that first emerged with the Deferred Action for Childhood Arrivals (DACA) program. See generally Jayesh M. Rathod, Crimmigration Creep: Reframing Executive Action on Immigration, 55 WASHBURN L.J. 173 (2015) (discussing the "significant misdemeanor" category of crimes and its impact on "crimmigration law").

31. 8 U.S.C. $§ 1226$ (c) (2012).

32. The category for "aggravated felony" convictions alone precludes many noncitizens from obtaining any form of immigration relief, and includes twenty-one types of offenses, as it has been expanded multiple times over the past two decades. 8 U.S.C. $§ 1101(\mathrm{a})(43)$; see also Stephen Legomsky, The New Path of Immigration Law: Asymmetric Incorporation of Criminal Justice Norms, 64 WASH. \& LEE L. REV. 469, 476-86 (2007) (detailing the growth of immigration-related crimes and immigration consequences of criminal convictions).

33. 8 U.S.C. $§ 1101(\mathrm{a})(43)(\mathrm{G})$ (2012). The categorical approach would govern whether a conviction under a particular state shoplifting statute is properly classified as an aggravated felony. 
immigration detention for a decades-old criminal conviction, even though they have already served their criminal sentence, and they are not a danger to the community or a flight risk. ${ }^{34}$ In these cases, the consideration of individualized, positive equities is usually not possible. ${ }^{35}$

Apart from highlighting the inequity in the immigration system, these provisions illustrate the impact that systems of criminalization have had on U.S. immigration processes. Immigration adjudicators place heavy emphasis on criminal conduct and on administrative violations, such as entering without inspection, that can also be prosecuted as crimes. As noted above, this growing criminal-immigration nexus is not a new phenomenon and has generated a significant body of literature. Many scholars have examined how criminal conduct is framed as a basis for enforcement in immigration $\operatorname{law}^{36}$ and how it relates to theories of membership more generally. ${ }^{37}$

Researchers and scholars have also examined the salience of race in criminal-immigration processes. As numerous observers have explained, the criminal justice system disproportionately impacts people of color and those with limited financial resources. ${ }^{38}$ At the federal level, immigration crimes, such as illegal re-entry, make up fifty percent of the federal criminal docket. ${ }^{39}$ These prosecutions disproportionately impact Latino

See, e.g., Omargharib v. Holder, 775 F.3d 192, 196 (4th Cir. 2014) (citing Descamps v. United States, 570 U.S. 254, 260-66 (2014)).

34. See 8 U.S.C. $\$ 1226(c)(1)$ (mandating detention of noncitizens convicted of certain offenses).

35. The inherent inequity in these systems has prompted litigation challenges, but few of these efforts have been successful. Advocates have successfully chipped away at the mandatory detention provision. For example, the Ninth Circuit ruled that bond hearings are required after six months in detention. Rodriguez v. Robbins, 804 F.3d 1060, 1078-86, 1090 (9th Cir. 2015) rev'd, Jennings v. Rodriguez, 138 S. Ct. 830 (2018). Other circuits have also articulated limitations, without adopting a specific timeframe. See Sopo v. U.S. Attorney Gen., 825 F.3d 1199, 1213-17 (11th Cir. 2016); Diop v. ICE/Homeland Sec., 656 F.3d 221, 235 (3d Cir. 2011).

36. See, e.g., Allegra M. McLeod, The U.S. Criminal-Immigration Convergence and its Possible Undoing, 49 AM. CRIM. L. REV. 105, 125-28 (2012) (discussing immigration enforcement's justification for its emphasis on noncitizens with criminal convictions); Legomsky, supra note 32, at 473 (arguing that the importation of the criminal justice model into immigration law has been asymmetric in its embrace of enforcement components without the corresponding procedural protections); Stumpf, supra note 16, at 382-87 (2006) (explaining three aspects of the intersections of criminal and immigration law: the expansion of criminal grounds for deportation and exclusion of noncitizens; growing use of criminal punishment based on immigration grounds; and focus on detention and deportation of noncitizens likely to commit crimes that pose a national security threat).

37. See, e.g., Linda Kelly, Defying Membership: The Evolving Role of Immigration Jurisprudence, 67 U. CIN. L. REV. 185 (1998) (arguing that forms of membership are gaining increased significance in immigration law).

38. See generally Michelle ALEXANDER, THE NeW JiM CROW: MASS INCARCERATION IN THE Age of Colorblindness (1st ed. 2010); David Cole, No EQual Justice: Race and Class in the AMERICAN CRIMINAL JUSTICE SYSTEM (1st ed. 1999).

39. See Immigration Now 52 Percent of All Federal Criminal Prosecutions, supra note 13 
communities, thus "feed[ing] the erroneous but rampant perception that immigrants have a higher propensity to commit crimes." the state and local levels, the same tools - such as racially disparate policing - that plague the criminal justice system, create the same racial imbalance for noncitizens funneled into immigration proceedings because of police stops, arrests, and criminal convictions. ${ }^{41}$ Enforcement activities by federal immigration agents also display evidence of racial profiling and bias. $^{42}$

Notwithstanding the inflexibility and bias in the system, there remain some areas where the government can exercise discretion. In those cases where criminal or administrative violations do not pose an absolute bar, adjudicators can often consider positive equities. Most commonly, these factors or equities are framed as connections to the United Statesduration of presence in the country, family ties within the United States, and property ownership. ${ }^{43}$ The length of one's stay in the United States is a commonly invoked justification for permitting someone to remain in the country, particularly when the individual has been in the United States since childhood and effectively knows no other home. ${ }^{44}$ This criterion also hearkens to other bodies of law, where claims or defenses ripen after specified periods of time. ${ }^{45}$ Various provisions of immigration law also

(finding that, in fiscal year 2016, criminal prosecutions for immigration violations, such as illegal reentry, made up fifty-two percent of all federal prosecutions).

40. Jennifer M. Chacón, Managing Migration Through Crime, 109 COLUM. L. ReV. SidEBAR 135,146 (2009).

41. A quintessential example is racial profiling by local law enforcement officers who embrace cooperation with federal immigration enforcement authorities. See, e.g., Press Release, U.S. Dep't of Homeland Sec., Statement by Secretary Napolitano on DOJ's Findings on Discriminatory Policing in Maricopa County (Dec. 15, 2011), https://www.dhs.gov/news/2011/12/15/secretary-napolitano-dojsfindings-discriminatory-policing-maricopa-county (concluding that the Maricopa County Sheriff's Office, led by Joe Arpaio, engaged in a practice of racially profiling Latino residents).

42. Some of this behavior is enabled by judicial precedent that permits the consideration of race in border enforcement. See César Cuauhtémoc García Hernández, La Migra in the Mirror: Immigration Enforcement and Racial Profiling on the Texas Border, 23 NOTRE DAME J.L. ETHICS \& PUB. POL’Y 167, 179-89 (2009).

43. Such factors are considered positive equities in cancellation of removal cases. See In re CV-T-, 22 I. \& N. Dec. 7, 11 (B.I.A. 1998) (discussing favorable considerations accounted for when considering requests for cancellation of removal).

44. Id. Indeed, the DACA program was explicitly framed as a discretionary act for certain individuals who met durational presence requirements. See Ming H. Chen, Beyond Legality: The Legitimacy of Executive Action in Immigration Law, 66 SYRACUSE L. REV. 87, 94-96 (2016).

45. An obvious comparison would be a statute of limitations, which forecloses the opportunity to bring suit after a specified period of time. Various observers have argued for a similar statute of limitations to apply to deportation. See, e.g., Andrew Tae-Hyun Kim, Deportation Deadline, 95 WASH. U. L. REV. 531 (2017) (discussing the abnormalities between the procedures in immigration law and non-immigration law, and proposing the use of a statute of limitations in deportation proceedings); Mae M. Ngai, We Need a Deportation Deadline, WASH. Post (June 14, 2005), 
place significant emphasis on the presence of U.S. citizen or permanent resident family members, and consider the hardship that these relatives may face if the noncitizen were removed from the country. ${ }^{46}$

Although various scholars have explored the salience of connections to the United States, ${ }^{47}$ there is surprisingly little theorizing about contributions that noncitizens make, and how these contributions should be weighed when making decisions about removal. While few would dispute that significant contributions to the United States should be a relevant factor, there is a lack of clarity and consensus regarding the types of contributions that militate in favor of discretionary immigration relief. The project of defining these contributions, and defending them theoretically, is critical to the effort of injecting more equity into the immigration system. Without a firm, theoretically grounded articulation of which positive equities matter, discourses of criminality will continue to erode the limited terrain of discretion.

In Part III of this article, we present a simple typology of contributions that should guide discretionary decision-making in immigration cases. As a preliminary step, however, we review the types of contributions deemed relevant in existing or previous laws and policies guiding administrative discretion for persons who are removable. Broadly, they can be divided into two categories: general contributions or service to the community, and specific types of contributions to the state. For the first category, in the context of an application for cancellation of removal, the Board of Immigration Appeals (BIA) has specified that "evidence of value and service to the community" is a positive equity that should be weighed when deciding whether to exercise discretion favorably. ${ }^{48}$ Along these lines, a June 2011 memorandum by former Immigration and Customs Enforcement (ICE) Director John Morton noted that a noncitizen's “ties and contributions to the community" should be considered when deciding

http:/www.washingtonpost.com/wp-dyn/content/article/2005/06/13/AR2005061301460.html (proposing that a statute of limitations in unauthorized presence prosecutions as "consistent with basic legal and moral principles"). Another analog is the concept of adverse possession in property law, whereby property rights accrue after land is occupied for a fixed period of time. See 142 AM. JUR. PROOF OF FACTS 3D 349 Acquisition of Title to Property By Adverse Possession $\S 1$ (2014).

46. The Immigration and Nationality Act contains various waiver provisions that examine potential hardships to U.S. citizens or lawful permanent resident family members. See, e.g., 8 U.S.C. $\S \S 1182(\mathrm{~h})-(\mathrm{i})(2012)$.

47. See, e.g., Hiroshi Motomura, Americans In Waiting: The Lost Story OF IMMIGRATION AND CITIZENSHIP IN THE UNITED STATES 18, 54 (2006) (describing the concept of "immigration as affiliation"); Elizabeth Keyes, Defining American: The DREAM Act, Immigration Reform and Citizenship, 14 Nev. L.J. 101, 124 (describing ways to frame the membership claims of DREAMers, based on their connections to the country).

48. In re $C-V-T-, 22$ I. \& N. at 11. 
whether to exercise prosecutorial discretion. ${ }^{49}$ These criteria are stated in very broad terms, and thus provide limited guidance. That said, one type of contribution that is specifically mentioned for cancellation of removal applicants is a history of employment. ${ }^{50}$

The second category of contributions deemed important are those that benefit the state in some fashion. First, government memos and case law consistently mention military service in the United States as a factor supporting an exercise of prosecutorial discretion. For example, a November 2000 memorandum from Immigration \& Naturalization Service (INS) Commissioner Doris Meissner specifies that "[m]ilitary service with an honorable discharge should be considered as a favorable factor." 51 Military service is similarly named as a positive equity in the 2011 Morton Memo, and in the factors that support cancellation of removal. ${ }^{52}$ The U.S. government has also considered support of other law enforcement functions to be a positive contribution weighing in the noncitizen's favor. The Meissner Memo states that "[c]urrent or past cooperation with the INS or other law enforcement authorities, such as the U.S. Attorneys, the Department of Labor, or National Labor Relations Board, among others, weighs in favor of discretion." 53 In his memorandum on prosecutorial discretion, ICE Director Morton adopted nearly identical language. ${ }^{54}$ In a memo issued contemporaneously, Director Morton also instructed ICE personnel to "exercise all appropriate discretion" in cases that involve "individuals pursuing legitimate civil rights complaints" and "individuals engaging in a protected activity related to civil or other rights." ${ }^{, 55}$ The language in these memos is

49. Memorandum from John Morton, Dir., U.S. Immigration \& Customs Enf't, to All Field Officer Dirs., Special Agents in Charge, \& Chief Counsel, on Exercising Prosecutorial Discretion Consistent with Immigration Enforcement Priorities 4 (June 17, 2011), https://www.ice.gov/doclib/secure-communities/pdf/prosecutorial-discretion-memo.pdf [hereinafter Morton Memo].

50. In re $C-V-T-, 22$ I. \& N. at 11 .

51. Memorandum from Doris Meissner, Dir., Immigration \& Naturalization Serv., to Reg'l Dirs., Dist. Dirs., Chief Patrol Agents, \& Reg'l \& Dist. Counsel, on Exercising Prosecutorial Discretion 8 (Nov. 17, 2000), http://library.niwap.org/wp-content/uploads/2015/IMM-Memo-ProsDiscretion.pdf [hereinafter Meissner Memo].

52. In re $C-V-T-, 22$ I. \& N. at 11 (stating that "service in this country's armed forces" is a relevant positive equity for cancellation of removal); Morton Memo, supra note 49, at 5 (categorizing "veterans and members of the U.S. armed forces" as a category meriting "particular care and consideration" when reviewing requests for prosecutorial discretion).

53. Meissner Memo, supra note 51, at 8.

54. Morton Memo, supra note 49, at 4 ("[T] he person is currently cooperating or has cooperated with federal, state or local law enforcement authorities, such as ICE, the U.S Attorneys or Department of Justice, the Department of Labor, or National Labor Relations Board, among others.").

55. Memorandum from John Morton, Dir., U.S. Immigration \& Customs Enf't, to All Field Office Dirs., Special Agents in Charge, \& Chief Counsel, on Prosecutorial Discretion: Certain 
consistent with $\mathrm{S}, \mathrm{T}$, and $\mathrm{U}$ nonimmigrant visa relief, which reward individuals for cooperating with law enforcement efforts to investigate and prosecute criminal activity. ${ }^{56}$

Although this precedent provides some helpful markers, the ambiguity allows space to reimagine the types of contributions that decision-makers should weigh favorably. Moreover, the relatively sparse precedent allows us to move beyond traditional, neoliberal conceptions of worthiness that privilege economic productivity and cultural assimilation by noncitizens, and instead consider a wider swath of contributions. ${ }^{57}$ For any vision of positive equities to be sustainable, however, strong theoretical foundations must support it. The subsection below details the theories of equity and membership that support consideration of a broad range of contributions by noncitizens.

\section{B. Theoretical Underpinnings}

Scholars have advanced various theories to explain why noncitizens have membership claims that should allow them to remain in the United States. Most of these theories equate membership with a more lasting status, such as lawful permanent residence or citizenship. ${ }^{58}$ The focus of this article, however, is on the considerations that should guide enforcement decisions, which can often take the form of a discretionary, and temporary, reprieve from removal. Permanent membership is, of course, substantively and procedurally distinct from a discretionary enforcement decision, ${ }^{59}$ and as a policy matter, one could easily justify distinct standards for the two. Nevertheless, these membership theories serve as a useful point of departure for the present analysis, as they consider factors that undergird a right to remain in the United States. An examination (and adaptation) of these theories reveals why it makes sense

Victims, Witnesses, and Plaintiffs 2 (June 17, 2011), https://www.ice.gov/doclib/foia/prosecutorialdiscretion/certain-victims-witnesses-plaintiffs.pdf. Note, however, that the memorandum does not explicitly frame this activity as a "contribution." A reasonable reading of the memorandum is that ICE intended to recognize that these activities should not be undermined and were thus worthy of a temporary reprieve from immigration enforcement.

56. See generally 8 U.S.C. $\S \S 1101(a)(15)(S)-(U)(2012 \&$ Supp. 2016).

57. See Muneer I. Ahmad, Beyond Earned Citizenship, 52 HARV. C.R.-C.L. L. Rev. 257, 261 (2017) (arguing, that in earned citizenship discourses, "worthiness is measured by economic productivity and moral rectitude").

58. See infra notes $68-70$ and accompanying text.

59. Lawful permanent residence is a formal legal status in the United States and is accompanied by specific substantive and procedural rights in the immigration context and in other areas of law. By contrast, a discretionary enforcement decision can be as simple as refraining from initiating removal proceedings against an undocumented noncitizen, thereby allowing that noncitizen to remain in the United States without authorization. 
to focus on noncitizens' contributions to the country as a way to inject more equity into the immigration system. Valuing contributions has intuitive appeal, but these theories illustrate the deeper relevance of this approach.

Before delving into any specific theory, it is worth acknowledging the moral dimensions of equity. Consideration of equity-that is, of fundamental fairness in social relationships, including relationships between individuals and institutional actors-is justified on moral grounds. ${ }^{60}$ Equity is also critical for the sustainability and legitimacy of any system of adjudication. ${ }^{61}$ As Henry E. Smith observes, "[e]quity benefits from basic morality to the extent that it is based on widely known and shared morals. $"{ }^{62}$ In the immigration context, equitable considerations can allow these everyday notions of fairness to temper otherwise rigid grounds of removal. ${ }^{63}$

Turning to specific theories, one widely discussed theory regarding the membership claims of noncitizens is jus nexi, advanced by Ayelet Shachar. ${ }^{64}$ In her work, Shachar builds upon the most common theoretical justifications for citizenship: jus soli (citizenship through birth in the country's territory) and jus sanguinis (citizenship through family relationships). ${ }^{65}$ These conceptions of citizenship provide an automatic claim for membership in different legal systems, but necessarily exclude large swaths of individuals who may be residing in a country's territory. ${ }^{66}$ Shachar introduces a new basis for a membership claim, beyond territorial birth or inherited citizenship: substantial connections to the country. ${ }^{67}$ Shachar therefore offers the phrase jus nexi as a way to describe this new legal principle that could underlie a membership claim. ${ }^{68}$

0. Duane Rudolph, Workers, Dignity, and Equitable Tolling, 15 Nw. J. Hum. RTs. 126, 140

61. Thomas O. Main, Traditional Equity and Contemporary Procedure, 78 WASH. L. REV. 429, 505 (2003).

62. Henry E. Smith, The Equitable Dimension of Contract, 45 Suffolk U. L. REv. 897, 913 (2012).

63. See M. Isabel Medina, Judicial Review - A Nice Thing? Article III, Separation of Powers and the Illegal Immigration Reform and Immigrant Responsibility Act of 1996, 29 CONN. L. REV. 1525, 1534-39 (1997) (describing attempts to harmonize inflexible removal provisions with considerations of fairness and moral legitimacy).

64. Ayelet Shachar, Earned Citizenship: Property Lessons for Immigration Reform, 23 YALE. J. L. \& HUMAN. 110, 115 (2011)

65. See generally id.

66. Id. at $118-19$.

67. Id. at 113-14 (discussing "rootedness" as the new framework for earned citizenship).

68. Id. at 115 . 
Shachar's theory emphasizes rootedness and connections as a justification for awarding earned citizenship. According to Shachar, "jus nexi demands that we focus on the 'actual relationships the individual has developed with a society: a family, friends, a job, association membership, professional acquaintances, opportunities." "69 Although it is framed in terminology related to citizenship, the jus nexi principle can also operate to confer permanent residence, a lesser status, or even to offer a simple reprieve from removal. ${ }^{70}$ While on a theoretical basis, jus nexi may equate with full membership, political realities might prevent conferral of citizenship. Therefore, insofar as jus nexi connotes a right to remain, it has relevance for the sizeable undocumented population in the United States, and whether some undocumented noncitizens should be insulated from expulsion. ${ }^{71}$

One potential shortcoming of Shachar's jus nexi principle is its limited exposition of the kinds of contributions that noncitizens can make. Shachar describes different dimensions of rootedness and types of social connections, many of which could serve as a reasonable proxy for contributions. $^{72}$ Shachar's article does mention employment, and acknowledges that the "ties that bind ... may include instances of civic engagement, such as being an active parent in a child's school, volunteering for community service, or caring for a needy relative." ${ }^{, 73}$ While these can certainly be classified as contributions, the range of noncitizen contributions is much broader, and sometimes occurs without other substantial ties to the United States. We therefore suggest a variant on the jus nexi model, which we call jus nexi et contributionum. This applies the same principles of jus nexi-that membership claims are based on substantial connections to, and rootedness in, the United States-and expands it slightly to include a more explicit focus on substantial contributions to the country. ${ }^{74}$ We contend that it is important to look not only to rootedness, but to the nature of the contributions that one makes to

69. Id. at 137 (quoting T. Alexander Aleinikoff, Aliens, Due Process and 'Community Ties': A Response to Martin, 44 U. PITT. L. REV. 237, 244 (1983)).

70. Id. at $155-56$.

71. Angela M. Banks, The Normative and Historical Cases for Proportional Deportation, 62 EMORY L.J. 1243, 1253 (2013).

72. Shachar, supra note 64 , at $137-39$.

73. Id. at 134

74. This framing builds upon the concept of "immigration as affiliation" advanced by Hiroshi Motomura, Who Belongs?: Immigration Outside the Law and the Idea of Americans in Waiting, 2 U.C. IRVINE L. REV. 359, 376 (2012). Like jus nexi, "immigration as affiliation" is premised on ties to the United States, but Motomura also includes contributions such as employment, payment of taxes, and civic engagement. $I d$. 
society. Substantial contributions, moreover, can compensate for fewer links to the country, and vice-versa.

Other theories help illustrate why the government should value contributions by noncitizens when making decisions regarding removal priorities. One is equity theory, which has birthed a strand of literature exploring inequity in social exchange. These works explore how imbalances in relationships lead to corresponding behavior change on the part of the actors. ${ }^{75}$ Although the foundational articles focus on employment relationships, ${ }^{76}$ the principles have been applied more broadly. ${ }^{77}$ The basic premise of equity theory is that persons engaged in relationships of social exchange (for example, employees working at a company) will assess their outcomes, along with corresponding inputs made, and modulate their behavior or perspective accordingly. ${ }^{78}$ Behavior change can also come about when similarly situated individuals experience the same outcomes for differing inputs. In the employment context, if two workers continue to receive the same wages (outcomes) for noticeably different levels of productivity (their inputs), over time, the more productive worker may choose to diminish her productivity, or even leave the position entirely, since she accrues no marginal benefit from her high input. ${ }^{79}$ In essence, the theory assumes that persons are motivated by concerns regarding distributive justice.

Equity theory has its limitations, of course, and does not capture all of the forces that guide human behavior. Indeed, an entire body of theory on procedural justice looks beyond outcomes to fairness of procedures and treatment. ${ }^{80}$ But equity theory does have value for understanding how persons make decisions around inputs and outcomes in the context of relationships. Accordingly, we offer that equity theory can be extended to the relationship between noncitizens and the state. Noncitizens provide

75. See generally J. Stacy Adams, Inequity in Social Exchange, 2 ADVANCES IN EXPERIMENTAL SOC. PSYCHOL. 267 (1965); J. Stacy Adams, Toward an Understanding of Inequity, 67 J. ABNORMAL \& SOC. PSYCH. 422 (1963) [hereinafter Understanding of Inequity]; Paul S. Goodman \& Abraham Friedman, An Examination of Adams' Theory of Inequity, 16 ADMIN. SCI. QUARTERLY 271 (1971).

76. See generally supra note 75.

77. Linda Hamilton Krieger, Afterword: Socio-Legal Backlash, 21 BERKELEY J. EMP. \& LAB. L. 476, 507 (2000) ("By the late 1970s, equity theory had developed into a general psychological theory of justice, broadly used to explain subjective perceptions of distributive fairness across a wide variety of interaction contexts.").

78. Understanding of Inequity, supra note 75, at 427-28.

79. Id.; see also Jeffrey L. Harrison, Class, Personality, Contract, and Unconscionability, 35 WM. \& MARY L. REV. 445, 458 (1994).

80. See, e.g., Emily Ryo, Less Enforcement, More Compliance: Rethinking Unauthorized Migration, 62 UCLA L. REV. 622, 667-69 (2015) (describing two types of procedural justice in the immigration system - fair decision-making and fair interpersonal treatment). 
various kinds of inputs in society, including employment, and other economic and social contributions. In exchange, the state reciprocates by offering some type of legal status that permits the noncitizen to remain in the United States. For those noncitizens lacking legal status, the noncitizen and the state may be parties to an implicit social contract in which the state agrees to forgo immigration enforcement (and thus exercise discretion favorably) in exchange for consistent economic contributions and no significant social disruptions (i.e., abstention from criminal activity). Hiroshi Motomura's formulation of "immigration as contract" contemplates these kinds of tacit reciprocal expectations shared between noncitizens and the state. ${ }^{81}$

Certainly, various factors complicate the application of equity theory to noncitizens, particularly those who are undocumented. One could argue that noncitizens understand themselves to be in a distinct class, and therefore, comparisons around outcomes would be made only with fellow noncitizens, who may experience similar treatment. ${ }^{82}$ Additionally, although equity theory suggests that actors in a relationship will modulate their behavior if the input-output ratio becomes skewed, noncitizens may have fairly low expectations regarding outcomes, especially in the current political moment. Indeed, various factors may lead a noncitizen to remain in the U.S. and to contribute economically and otherwise - even with the looming specter of immigration enforcement, and with little expectation that the government will uphold its end of the implicit bargain. ${ }^{83}$ All that said, one can still imagine a scenario where the state places such little value on the contributions that noncitizens make, or where the contributions involve putting oneself at risk, that the inequity in the relationship becomes unsustainable. In such a scenario, noncitizens may cease making contributions, withdraw from the community, or even depart the United States and relocate to a different country. To be sure, the government may have the objective of encouraging people (especially the undocumented) to disengage from the community or leave the country. This approach is

81. Motomura, supra note 74 , at 373-74.

82. Adams suggested that one way individuals may respond to perceived inequity is to "change his referent Other" and instead draw comparisons with someone more similar. Understanding of Inequity, supra note 75, at 429.

83. Cf. Jayesh M. Rathod, Danger and Dignity: Immigrant Day Laborers and Occupational Risk, 46 SETON HALl L. REV. 813, 862-63 (2016) (describing how economic insecurity leads immigrants to remain in unsafe, exploitative conditions of work); Gray Albert Abarca \& Susan Bibler Coutin, Sovereign Intimacies: The Lives of Documents Within U.S. State-Noncitizen Relationships, 45 AM. ETHNOLOGIST 7, 8-9 (2018) (describing the complex relationship between noncitizens and the state, including the vulnerability of noncitizens to abuse and mistreatment, at times mediated by acts of "administrative grace"). 
unlikely to be sustainable on a large scale given U.S. society's significant economic and social dependence on noncitizens. ${ }^{84}$ Therefore, an approach to immigration enforcement that contemplates these dynamics of equity theory-and therefore rewards in some way the contributions that noncitizens make - could avoid such potential outcomes.

A final bundle of theories, related to equity theory, are those relating to rational choice. These theories posit that individuals make decisions regarding civic or political participation based on their rational selfinterest. ${ }^{85}$ Therefore, when choosing to work with or on behalf of the government, individuals will assess how it benefits them, economically or otherwise, and will seek to ensure that the benefits outweigh any costs. ${ }^{86}$ Rational choice theorists have appropriately problematized the concept of "self-interest," emphasizing the different imperatives and values that drive individual decision-making. ${ }^{87}$ Despite its inherent complexity, rational choice theory is a helpful frame for understanding the behavior of noncitizens. ${ }^{88}$ In many respects, it is similar to equity theory's examination of inputs and outcomes, but with a specific focus on individuals' engagement with governmental or political processes. Since the government relies heavily on cooperation by persons within the country's territory - including noncitizens - rational choice theory instructs us to assess the factors that will motivate individuals to cooperate.

It is critical to examine how immigration enforcement dynamics shape noncitizens' willingness to assist the government. Currently, the U.S. government relies on noncitizens for cooperation on a range of matters, from everyday interactions to high-stakes law enforcement and national security efforts. Through the $\mathrm{T}$ and $\mathrm{U}$ nonimmigrant visa programs, for example, the U.S. government has sought to incentivize reporting and cooperation regarding criminal activity, with the eventual reward being the possibility of legal status in the United States. ${ }^{89}$ Noncitizens support many other government functions, including military operations and the

\footnotetext{
84. See Audrey Singer, Brookings Institute, Immigrants in the U.S. Labor Force (Mar. 15, 2012), https://www.brookings.edu/wp-content/uploads/2016/06/0315_immigrant_workers_singer.pdf (analyzing U.S. dependence on an immigrant labor force).

85. See Charles Pattie, Patrick Seyd, \& Paul Whiteley, Citizenship \& Civic Engagement: Attitudes and Behaviour in Britain, 51 POL. STUD. 443, 443-44 (2003).

86. Cf. Jan E. Leighley, Attitudes, Opportunities and Incentives: A Field Essay on Political Participation, 48 POL. RES. Q. 181, 192 (1995) (discussing the rationality of participation in the political arena and voter turnouts).

87. Donald P. Green \& Ian Shapiro, Pathologies of Rational Choice Theory: A CRitiQue OF APPLiCATIONS IN POLITICAL SCIENCE 18-19 (1994).

88. See, e.g., Sonja Haug, Migration Networks and Migration Decision-Making, 34 J. ETHNIC \& MigRATION STUD. 585, 586-88 (2008).

89. See infra notes $106-11$ and accompanying text.
} 
work of administrative agencies. ${ }^{90}$ Affirmative incentives are likely to yield greater contributions, particularly when they include a means to remain in the United States. Conversely, if noncitizens learn that their contributions will have no effect on their ability to remain in the United States, such contributions may decline. And what if the contributions or other assistance make removal more likely? That will almost certainly lead to a decrease in cooperation among noncitizens. A rationallythinking, self-interested actor is unlikely to take such a risk. This suggests that for states to continue to benefit from different kinds of contributions by noncitizens, some basic incentives must be in place for the noncitizen. At a minimum, the noncitizen must have a guarantee that their assistance will not ultimately harm them. Since these contributions are critical for the government, equity theory and rational choice theory instruct us that rewarding contributions in discretionary immigration enforcement decisions is ultimately beneficial to the United States.

\section{BUILDING EQUITY INTO CONTEMPORARY IMMIGRATION ENFORCEMENT}

We suggest that two types of contributions by noncitizens should be given significant consideration in the context of immigration enforcement decisions. An explication of these categories of contributions and the theories justifying them as an important equity are detailed below. In Section A, we define the two categories - (1) sustained economic, social, and cultural contributions; and (2) substantial and/or sustained contributions that support the government-and provide specific examples within each category. These are summarized in Table 1, below. In Section B, we discuss how criminalization, in three specific forms, affects the weight given to these positive equities, as well as the current administration's shift such that some contributions, which were once considered positive equities, become tainted with labels of criminality.

90. See infra notes $112-26$ and accompanying text. 
TABLE 1: Typology of Contributions and Theoretical Justifications

\begin{tabular}{|l|l|l|}
\hline $\begin{array}{l}\text { Type of } \\
\text { Contribution }\end{array}$ & $\begin{array}{l}\text { Sustained economic, social, or } \\
\text { cultural contributions to families, } \\
\text { communities, or society at large, } \\
\text { but that do not affirmatively or } \\
\text { indirectly support government } \\
\text { functions }\end{array}$ & $\begin{array}{l}\text { Substantial and/or } \\
\text { sustained } \\
\text { contributions that } \\
\text { support a government } \\
\text { function, either } \\
\text { indirectly or directly }\end{array}$ \\
\hline Example & $\begin{array}{l}\text { Engaging in low-wage work; } \\
\text { providing economic and other } \\
\text { support for family members, } \\
\text { including U.S. citizens and } \\
\text { lawful permanent residents } \\
\text { (LPRs); other forms of sustained } \\
\text { community service and } \\
\text { engagement }\end{array}$ & $\begin{array}{l}\text { Reporting a crime to } \\
\text { law enforcement; } \\
\text { reporting workplace } \\
\text { violations; serving as } \\
\text { an Office of Refugee } \\
\text { Resettlement sponsor } \\
\text { for an unaccompanied } \\
\text { minor; military service }\end{array}$ \\
\hline $\begin{array}{l}\text { Theoretical } \\
\text { Justifications }\end{array}$ & $\begin{array}{l}\text { Modified jus nexi (jus nexi et } \\
\text { contributionum); moral } \\
\text { imperatives }\end{array}$ & $\begin{array}{l}\text { Modified jus nexi; } \\
\text { moral imperatives; } \\
\text { plus equity theory and } \\
\text { rational choice theory }\end{array}$ \\
& & \\
\hline
\end{tabular}

\section{A. Types of Contributions}

This article focuses on two categories of contributions: sustained economic, social, and cultural contributions that benefit families, communities, and society at large; and sustained and/or substantial contributions that support government functions. The purpose of creating the two categories is to distinguish sustained, yet commonplace, contributions, such as participation in the workforce or provision of financial and other support to one's family, from those contributions that assist the government, whether directly or indirectly. As noted above, while there is somewhat limited existing guidance on contributions that should receive positive weight in immigration enforcement decisions, the previously articulated guidelines do roughly track these two categories. ${ }^{91}$ This section endeavors to articulate with more specificity, by way of concrete examples, the types of contributions by noncitizens that decisionmakers should consider. The examples that follow are not meant to be

91. See supra notes $48-56$ and accompanying text. 
exhaustive; rather, they illustrate just a few of the many contributions made by noncitizens that fall into these categories.

The economic, social, and cultural contributions contemplated by the first category encompass a wide range of activities and actions. The category is framed explicitly to include cultural contributions, since existing immigration law provisions already reward economic, and to a lesser extent, social contributions. For example, under existing law, some noncitizens in removal proceedings may apply for a limited form of relief called cancellation of removal, which is available to both LPRs and others with long-term presence in the country. ${ }^{92}$ For LPRs, positive equities for cancellation include history of employment, business or property ties, and service to the community, among others. ${ }^{93}$ Applicants who are not LPRs face more burdensome requirements and must show, among other things, "exceptional and extremely unusual hardship to the [applicant's] spouse, parent, or child, who is a [U.S. citizen] or [LPR]." " While this is a very high standard, it recognizes contributions made to immediate family members, including financial and emotional support. ${ }^{95}$ Along these lines, the Deferred Action for Childhood Arrivals (DACA) program attached value to educational credentials, ${ }^{96}$ which is arguably a predicate to broader economic and social contributions. ${ }^{97}$

This category endeavors to capture an even broader range of economic, social, and cultural contributions, beyond those currently recognized under immigration law. For example, although the non-LPR cancellation factors recognize caretaking and support as important

92. See 8 U.S.C. $\S 1229$ b (2012) (detailing the requirements for cancellation of removal for permanent and nonpermanent residents).

93. In re C-V-T-, 22 I. \& N. Dec. 7, 11 (B.I.A. 1998).

94. 8 U.S.C. $\S 1229 \mathrm{~b}(\mathrm{~b})(1)(\mathrm{D})$

95. See In re Recinas, 23 I. \& N. Dec. 467, 471 (B.I.A. 2002) (concluding that the respondent met the exceptional and extremely unusual hardship standard because she was the sole provider for six children, four of whom were U.S. citizens, and she had no family in Mexico).

96. Although the DACA program has since been terminated, USCIS electronically maintains the information. See Consideration of Deferred Action for Childhood Arrivals (DACA), U.S. CITIZENSHIP \& IMMIGR. SERVS., https://www.uscis.gov/archive/consideration-deferred-action-childhood-arrivalsdaca\#guidelines (last updated Feb. 14, 2018) (listing the qualifications for DACA, including that an applicant must either currently be in school, have graduated high school, obtained a GED, or been honorably discharged from the Armed Forces of the United States).

97. In holding that the state could not refuse to provide public education to undocumented children, the Supreme Court stated,

[E]ducation provides the basic tools by which individuals might lead economically productive lives to the benefit of us all. In sum, education has a fundamental role in maintaining the fabric of our society. We cannot ignore the significant social costs borne by our Nation when select groups are denied the means to absorb the values and skills upon which our social order rests.

Plyler v. Doe, 457 U.S. 202, 221 (1982). 
contributions, the circumstances need not rise to the level of exceptional and extremely unusual hardship to count as a positive equity. ${ }^{98}$ Other relevant social and cultural contributions may include sustained volunteer work on a child's parent-teacher association, running a business that provides space for community events, or creating impactful art. Many undocumented immigrants have demonstrated leadership as advocates and organizers for immigration-related issues; these activists have advocated publicly on behalf of themselves and others, despite fears of being targeted and prosecuted for deportation. ${ }^{99}$ Some noncitizens contribute to other causes, including those that affect youth and LGBT rights. ${ }^{100}$ Other contributions may be even less apparent - take the example of a wellknown subway performer, who provides joy to daily commuters. This type of contribution rarely receives formal recognition, yet it still can have a significant cultural and social impact. While this impact can be difficult to quantify in terms of its economic value, this category of contributions seeks to look beyond traditional metrics of worthiness.

The category is defined to include only sustained contributions, as the duration of the contribution is critical to consider. Immigration law has already signaled the importance of lasting contributions, as reflected in requirements for continuous periods of presence (typically, five or ten years) for some forms of relief. ${ }^{101}$ Because this approach requires a more case-specific assessment of various equities, one way to factor in duration is to give more weight to the contribution for each year it is made or maintained. That said, in evaluating contributions made by a noncitizen, a minimum duration should not necessarily be required. This model for decision-making emphasizes individualized evaluations of equities, so the duration need not be identical in each case.

98. See In re Monreal-Aguinaga, 23 I. \& N. Dec. 56, 58-63 (B.I.A. 2001) (explaining the exceptional and extremely unusual hardship standard for non-LPR cancellation of removal).

99. Allegra M. McLeod, Immigration, Criminalization, and Disobedience, 70 U. MIAMI L. REV. 556, 570-81 (2016) (detailing political actions led by undocumented youth organizers). Early in 2018, several prominent undocumented activists were targeted by immigration enforcement. See, e.g., Amy Gottlieb, ICE Detained My Husband for Being an Activist, N.Y. TIMES (Jan. 18, 2018), https://www.nytimes.com/2018/01/18/opinion/ravi-ragbir-immigration-ice.html; Nina Shapiro, Activist Maru Mora-Villalpando Says ICE Using Deportation Threat as 'Intimidation Tactic,' SEATTLE TIMES (Jan. 16, 2018), https://www.seattletimes.com/seattle-news/activist-maru-moravillalpando-says-ice-using-her-deportation-as-intimidation-tactic/.

100. Alan Pelaez Lopez, 10 (Un)documented Black and LGBTQIA+ Activists You Need to Know, BGD BLOG (Mar. 29, 2016), https://www.bgdblog.org/2016/03/10-undocumented-black-and-lgbtqiaactivists-you-need-to-know/.

101. For example, cancellation of removal for non-LPRs requires ten years of continuous presence in the United States, while cancellation for LPRs requires only seven years of continuous residence. 8 U.S.C. $\S 1229 b$ (a), (b) (2012). To obtain citizenship, one must first be a LPR for a period of five years prior to applying for naturalization. Id. § 1427(a). 
The broader impact of the contribution must also be considered. Again, looking to cancellation of removal for non-LPRs, under existing law, only hardship to U.S. citizen or permanent resident children, spouses, or parents is considered. ${ }^{102}$ When determining the weight afforded to contributions, however, the status of the beneficiary should not be relevant. Activists who work for social change on behalf of a community benefit many, even though the beneficiaries may be neither immediate family members nor U.S. citizens or LPRs. For example, DACA recipients and other DREAMers who have become politically active may work primarily on behalf of the undocumented community. ${ }^{103}$ That sustained social contribution should nonetheless be weighed as a positive equity. While adjudicators may be reluctant to consider contributions that benefit undocumented immigrants, those beneficiaries form a substantial part of the overall community and many have lived in the country for years. ${ }^{104}$ In examining the broader context and impact of the contribution, it is important to consider equity theory, one of the theoretical underpinnings of jus nexi et contributionum. In order to incentivize specific contributions, or inputs, that benefit the broader community, the state must recognize the value of these contributions.

The second category of contributions is distinguishable from the first, as this set of substantial and/or sustained contributions supports government functions, either directly or indirectly. Similar to the first category, the quantum of the contribution, as measured by its weightiness or duration, is a key factor. Some of these contributions are already built into immigration law, as the government has recognized the importance of encouraging noncitizens to make such contributions. ${ }^{105}$

For example, reporting specific criminal activity and assisting with prosecutions is a contribution that has been recognized in immigration law. The Victims of Trafficking and Violence Protection Act of 2000 (VTVPA) made immigrant victims of specific categories of crimes eligible to receive

\footnotetext{
102. 8 U.S.C. $\S 1229 b(b)(1)(D)$.

103. See Tania A. Unzueta Carrasco \& Hinda Seif, Disrupting the Dream: Undocumented Youth Reframe Citizenship and Deportability Through Anti-Deportation Activism, 12 LATINO STUD. 279, 289-92 (2014) (describing how undocumented youth have led efforts to combat deportations).

104. U.S. Unauthorized Immigration Population Estimates, PEW RES. CTR.: HisPaniC TRENDS (Nov. 3, 2016), http://www.pewhispanic.org/interactives/unauthorized-immigrants/; see also Jeffrey S. Passel \& D'Vera Cohn, As Mexican Share Declined, U.S. Unauthorized Immigrant Population Fell in 2015 Below Recession Level, PEW RES. CTR.: FACT TANK (Apr. 25, 2017), http://www.pewresearch.org/fact-tank/2017/04/25/as-mexican-share-declined-u-s-unauthorizedimmigrant-population-fell-in-2015-below-recession-level/ (stating that the undocumented population declined slightly from 11.3 million in 2009 to 11 million in 2015).

105. See supra Section II.A.
} 
a $\mathrm{U}$ visa. ${ }^{106}$ In order to receive the $\mathrm{U}$ visa, these victims must submit a law enforcement certification signed by a law enforcement agency, judge, or prosecutor that affirms that the recipient and crime victim assisted in the investigation of the crime. ${ }^{107}$ In other words, the $U$ visa was designed to incentivize noncitizens to report criminal activity, and to support investigative and prosecutorial efforts. ${ }^{108}$ Since the VTVPA of 2000, subsequent legislation expanded the list of qualifying crimes that make immigrant victims eligible for a U visa. ${ }^{109}$ Similarly, the Trafficking Victims Protection Act (TVPA) provides that victims of trafficking may be eligible to receive a T visa. ${ }^{110}$ Like the $\mathrm{U}$ visa, the purpose of the T visa is to facilitate reporting of trafficking incidents and criminal investigations of alleged misconduct. ${ }^{111}$

Another clear example of a contribution that directly aids in a government function is military service. Military service has been

106. Violence Against Women Act of 2000 (VTVPA), Pub. L. No. 106-386, § 1513, 114 Stat. 1464, 1533-1537 (2000).

107. The exact language of the statute requires that

the alien (or in the case of an alien child under the age of 16, the parent, guardian, or next friend of the alien) has been helpful, is being helpful, or is likely to be helpful to a Federal,

State, or local law enforcement official, to a Federal, State, or local prosecutor, to a Federal or State judge, to the Service, or to other Federal, State, or local authorities investigating or prosecuting criminal activity. ...

8 U.S.C. $\S 1101(\mathrm{a})(15)(\mathrm{U})(\mathrm{i})(\mathrm{III})(2012)$.

108. See Victims of Criminal Activity: U Nonimmigrant Status, U.S. CitiZENSHIP \& IMMIGR. SERVS., https://www.uscis.gov/humanitarian/victims-human-trafficking-other-crimes/victims-crimi nal-activity-u-nonimmigrant-status/victims-criminal-activity-u-nonimmigrant-status (last updated Aug. 25, 2017) ("The legislation was intended to strengthen the ability of law enforcement agencies to investigate and prosecute cases of domestic violence, sexual assault, trafficking of aliens and other crimes, while also protecting victims of crimes who have suffered substantial mental or physical abuse due to the crime and are willing to help law enforcement authorities in the investigation or prosecution of the criminal activity.").

109. See, e.g., Violence Against Women Reauthorization Act of 2013, Pub L. No. 113-4, §§ 801, 1222, 127 Stat. 54, 110, 144; see also Memorandum from U.S. Citizenship \& Immigration Servs. on Violence Against Women Reauthorization Act of 2013: Changes to U Nonimmigrant Status and Adjustment of State Provisions 2-3 (Apr. 15, 2015), https://www.uscis.gov/site s/default/files/files/nativedocuments/2015-0415-TVPRA-2013-PM.pdf (explaining that stalking and fraud in foreign labor contracting were added in the VAWA 2013 and listing the qualifying crimes for U nonimmigrant status).

110. Trafficking Victims Protection Act of 2000, Pub. L. No. 106-386, § 107(e)(1), 114 Stat. 1464, 1477-78 (2000). Among other T Visa requirements, a person must be a victim of a "severe form of trafficking," which is defined as either "sex trafficking in which a commercial sex act is induced by force, fraud, or coercion, or in which the person induced to perform such act has not attained 18 years of age" or "the recruitment, harboring, transportation, provision, or obtaining of a person for labor or services, through the use of force, fraud, or coercion for the purpose of subjection to involuntary servitude, peonage, debt bondage, or slavery." Id. at §103(8).

111. See 22 U.S.C. $\$ 7101$ (a) (2012) (stating the purpose of the TVPA is "to combat trafficking in persons, a contemporary manifestation of slavery whose victims are predominantly women and children, to ensure just and effective punishment of traffickers, and to protect their victims"). 
recognized as a positive equity in immigration proceedings, and it has provided an expedited path to citizenship. ${ }^{112}$ One recruitment program, known as the Military Accessions Vital to National Interest (MAVNI) program, allowed noncitizens with specific abilities, such as physicians, nurses, and foreign language experts to enroll in the U.S. military. ${ }^{113}$ The program was in place through September 30, 2016. ${ }^{114}$ The current administration did not explicitly continue the program, and instead, reportedly cancelled recruitment contracts for noncitizen recruits. ${ }^{115}$ In the fall of 2017, the Pentagon announced policy changes for recruiting noncitizens to the military, including additional security screening measures for LPRs and an extended period of time in active service for foreign nationals. ${ }^{116}$

Other types of contributions in this category indirectly support a government function. One such example is the assistance that noncitizens provide as "sponsors" for unaccompanied minors ${ }^{117}$ who find themselves in government custody. The Homeland Security Act of 2002 transferred functions related to placement and care of unaccompanied minors to the Office of Refugee Resettlement (ORR). ${ }^{118}$ ORR is responsible for coordinating the care and placement of unaccompanied minors, taking into account the best interests of the child. ${ }^{119}$ In coordination with ORR, sponsors for unaccompanied minors agree to shepherd the child through the court process and to ensure that he or she appears at each hearing before the immigration judge. ${ }^{120}$ Many sponsors for unaccompanied

112. See Cathy Ho Hartsfield, Note, Deportation of Veterans: The Silent Battle for Naturalization, 64 RUTGERS L. REV. 835, 844-46 (2012) (detailing the steps noncitizens who serve in the military must take to naturalize and the challenges they face in doing so).

113. Military Accessions Vital to National Interest (MAVNI) Recruitment Pilot Program, U.S. DEP'T DEF., https://www.defense.gov/news/mavni-fact-sheet.pdf (last visited Apr. 5, 2018).

114. Broadcast Message from U.S. Immigration \& Customs Enf't Serv., to All Student \& Exch. Visitor Info. Sys. Users, on MAVNI Program Status for Fiscal Year 2017, 1 (Dec. 2, 2016), https://www.ice.gov/doclib/sevis/pdf/bcm-1612-02.pdf.

115. Alex Horton, U.S. Army Kills Contracts for Hundreds of Immigrant Recruits. Some Face Deportation, WASH. POST (Sept. 15, 2017), https://www.washingtonpost.com/news/checkpoin t/wp/2017/09/15/army-kills-contracts-for-hundreds-of-immigrant-recruits-sources-say-some-facedeportation/?utm_term=.ce7d4e9129ff.

116. Press Release from U.S. Dep't of Def. on DoD Announces Policy Changes to Lawful Permanent Residents and the Military Accessions Vital to the National Interest (MAVNI) Pilot Program (Oct. 13, 2017), https://www.defense.gov/News/News-Releases/News-Release-View/Ar ticle/1342317/dod-announces-policy-changes-to-lawful-permanent-residents-and-the-military-acc/.

117. See 6 U.S.C. $\$ 279(\mathrm{~g})(2)$ (2012) (defining an unaccompanied minor, or "unaccompanied alien child," as a child under the age of 18 who has no lawful immigration status and no parent or legal guardian either in the United States or available to provide care and physical custody).

118. Id. § 279 .

119. Id.

120. See Unaccompanied Children Program: ORR/DCS Family Reunification Packet for 
minors are noncitizens, as lawful immigration status is not a requirement for serving as a sponsor. ${ }^{121}$ Beginning in 2014, these sponsors, or care providers, were required to disclose their immigration status as part of their application for sponsorship. ${ }^{122}$

Reporting a danger in the workplace is another contribution that indirectly supports a government function, as it is analogous to reporting crimes to law enforcement; it helps worksite enforcement agencies monitor compliance and can trigger investigations of potentially dangerous work environments. ${ }^{123}$ Encouraging workers to report occupational hazards is one important way to achieve workplace safety. ${ }^{124}$ Even workers who seek workers' compensation for occupational injuries indirectly benefit workplace safety, as they put on the record specific workplace danger(s) that others may encounter. ${ }^{125}$ This contribution made

Sponsors, Sponsor Care Agreement, U.S. DeP'T HeAlth \& HuMAN SERVs., OffiCE REFugEE RESETTLEMENT (Aug. 9, 2012), https://www.acf.hhs.gov/orr/resource/unaccompanied-childrensservices (detailing the duties of a sponsor of an unaccompanied minor released from ORR, including "provid[ing] for the physical and mental well-being of the minor" and "ensur[ing] the minor's presence at all future proceedings before the DHS/Immigration and Customs Enforcement (ICE) and the $\mathrm{DOJ} / \mathrm{EOIR}$ ").

121. See SARAH PIERCE, Unaccompanied Child Migrants in U.S. Communities, Immigration Court, and Schools, 2015 MIGRATION POL'Y INST. POL'Y BRIEF, at 1, https://www.migrationpolicy.org/research/unaccompanied-child-migrants-us-communities-

immigration-court-and-schools (stating that unaccompanied children are placed with sponsors who live in areas with high foreign-born populations); Children Entering the United States Unaccompanied: Section 2: Safe and Timely Release from ORR Care, U.S. DEP'T HEALTH \& HUMAN SERVS.: OFFICE REFUGEE RESETTLEMENT, https://www.acf.hhs.gov/orr/resource/children-enteringthe-united-states-unaccompanied-section-2\#2.1 (last reviewed Dec. 4, 2017) (explaining requirements for sponsorship).

122. See Sponsors and Placement: Release of Unaccompanied Alien Children to Sponsors in the U.S., U.S. DEP'T HeAlth \& Human SERvs.: OfFice RefugeE Resettlement, https://www.acf.hhs.gov/orr/about/ucs/sponsors (last reviewed June 30, 2017) ("In this determination process, immigration status information is requested of sponsors, and also may emerge through the background checks. Since January 2014, care providers have been required to enter this information into the ORR portal, a procedure that was optional until that time. Immigration status information, however, is not used to disqualify potential sponsors. Instead, it is used to ensure the safety and wellbeing of the child by making sure that there is an adequate care plan in place that takes all relevant aspects of the sponsor's situation into consideration.").

123. See U.S. DEP'T OF LABOR, OCCUPATIONAL SAFETY \& HEALTH ADMIN., OSHA FACT SHEET: OSHA INSPECTIONS (2016), https://www.osha.gov/OshDoc/data_General_Facts/factsheetinspections.pdf (noting that worker complaints of hazardous or dangerous conditions are given "high priority" in allocating inspection resources).

124. Among other goals, two stated purposes for the Occupational Safety and Health Act (OSHA) are: "encouraging employers and employees in their efforts to reduce the number of occupational safety and health hazards at their places of employment, and to stimulate employers and employees to institute new and to perfect existing programs for providing safe and healthful working conditions" and "providing for appropriate reporting procedures with respect to occupational safety and health which procedures will help achieve the objectives of this chapter and accurately describe the nature of the occupational safety and health problem." 29 U.S.C. $§ 651(b)(1),(12)$.

125. See Jayesh M. Rathod, Immigrant Labor and the Occupational Safety and Health Regime, 
by immigrant workers is especially important, because many immigrant workers, particularly those who are undocumented, labor in positions that have high rates of occupational injury. ${ }^{126}$

Having examined the contours of these two categories of contributions - (1) sustained social, cultural and economic contributions, and (2) sustained and/or substantial contributions that support a government function, either directly or indirectly-the next section describes how criminalization taints both categories of contributions. Criminalization of the latter category is a relatively new phenomenon and is especially problematic. As discussed in more detail, some contributions have received affirmative recognition in immigration law and lead to relief or a path to citizenship; yet in some instances, the noncitizens who should be rewarded for making such contributions instead face criminal or immigration-related consequences. The most troubling scenario is one in which the contribution is itself criminalized, sometimes indirectly, thus flipping what should be a positive equity to a negative one.

\section{B. Shrinking Equities through Criminalization}

Over the past few decades, immigration discretion evolved such that criminal history has become a primary factor for denying various forms of immigration relief. ${ }^{127}$ In the current climate, the limited spaces where contributions can be considered are themselves being tainted by criminalization. ${ }^{128}$ The effect is to narrow even further the opportunities

33 N.Y.U. ReV. L. \& Soc. Change 479, 540 (2009) (suggesting that state workers' compensation records may serve as useful data for the Occupational Safety and Health Administration (OSHA) to track injuries and illnesses in the workplace).

126. See id. at 490-97 (2009) (examining specific industries with high rates of occupational fatalities and injuries that also have high rates of employment of undocumented workers).

127. See Cade, supra note 25, at 663-64 (2015) (noting that in the late twentieth century, "amendments to the immigration code heralded the rise of criminal history, very broadly defined, as the primary marker of undesirability, while squeezing consideration of humanitarian or fairness concerns almost completely out of the adjudicative stages of deportation or criminal proceedings"). One concrete example is that noncitizens are barred from seeking asylum if they have been convicted of a particularly serious crime. 8 U.S.C. § 1158(b)(2)(A)(ii) (2012).

128. As described more fully below, these "spaces" correspond to portions of substantive law that allow for the exercise of discretion. But the current administration has also altered the physical terrain of enforcement. Under President Trump, the DHS has prioritized interior enforcement over arrests at the border, which in effect targets individuals who have resided in the United States for some period of time. See U.S. ImMigration \& Customs EnF'T, FisCAL YeAR 2017 ICE ENForCEMENT AND REMOVAL OPERATIONS REPORT 11 (2017), https://www.ice.gov/sites/default/files/documents/ Report/2017/iceEndOfYearFY2017.pdf (stating that an increased emphasis on interior enforcement led to the highest number of ICE administrative arrests in the past three years); Kristen Bialik, ICE Arrests Went Up in 2017, With Biggest Increases in Florida, Northern Texas, Oklahoma, PEw ReS. CTR.: FACT TANK (Feb. 8, 2018), http://www.pewresearch.org/fact-tank/2018/02/08/ice-arrests-wentup-in-2017-with-biggest-increases-in-florida-northern-texas-oklahoma/. 
for noncitizens to seek relief or a reprieve from removal. The table below defines three different forms of criminalization that impact noncitizens: (1) direct criminalization of contributions; (2) indirect criminalization of contributions; and (3) separate criminal activity that dilutes the positive impact of contributions. These three forms of criminalization have begun to change how contributions are framed, and thus how equities are weighed in the context of discretionary enforcement decisions.

TABLE 2: Forms of Criminalization that Impact Noncitizens and their Contributions

\begin{tabular}{|l|l|l|l|}
\hline $\begin{array}{l}\text { Type of } \\
\text { criminalization }\end{array}$ & Definition & $\begin{array}{l}\text { Examples: sustained } \\
\text { economic, social, and } \\
\text { cultural contributions }\end{array}$ & $\begin{array}{l}\text { Examples: } \\
\text { support of } \\
\text { government } \\
\text { functions }\end{array}$ \\
\hline $\begin{array}{l}\text { Direct } \\
\text { criminalization }\end{array}$ & $\begin{array}{l}\text { The very act } \\
\text { that could be } \\
\text { framed as a } \\
\text { contribution is } \\
\text { criminalized }\end{array}$ & $\begin{array}{l}\text { Laws that seek to } \\
\text { criminalize the act of } \\
\text { seeking/soliciting work } \\
\text { by unauthorized } \\
\text { persons }\end{array}$ & N/A \\
\hline $\begin{array}{l}\text { Indirect } \\
\text { criminalization }\end{array}$ & $\begin{array}{l}\text { Corollary or } \\
\text { predicate acts } \\
\text { are } \\
\text { criminalized; } \\
\text { or, } \\
\text { criminalization } \\
\text { generates } \\
\text { conditions that } \\
\text { make the act } \\
\text { impossible }\end{array}$ & $\begin{array}{l}\text { Prosecutions for use of } \\
\text { false documents to } \\
\text { obtain employment; } \\
\text { criminalization that } \\
\text { circumscribes mobility } \\
\text { or visibility (and hence } \\
\text { inhibits societal } \\
\text { engagement), such as } \\
\text { state-specific driver's } \\
\text { license restrictions } \\
\text { based on immigration } \\
\text { status }\end{array}$ & $\begin{array}{l}\text { Reporting labor } \\
\text { violations is } \\
\text { criminalized } \\
\text { through } \\
\text { perversion of } \\
\text { insurance rules; } \\
\text { ORR sponsors } \\
\text { are criminalized } \\
\text { for the related } \\
\text { act of facilitating } \\
\text { the unlawful } \\
\text { entry of children }\end{array}$ \\
\hline $\begin{array}{l}\text { Separate } \\
\text { criminal } \\
\text { activity }\end{array}$ & $\begin{array}{l}\text { Separate } \\
\text { behavior, } \\
\text { unrelated or } \\
\text { loosely related } \\
\text { to a specific } \\
\text { contribution, } \\
\text { that overrides } \\
\text { the importance } \\
\text { of the } \\
\text { contribution }\end{array}$ & $\begin{array}{l}\text { Any kind of criminal } \\
\text { activity }\end{array}$ & $\begin{array}{l}\text { Any kind of } \\
\text { criminal activity }\end{array}$ \\
\hline
\end{tabular}


In examining how contributions should be weighed vis-à-vis criminal conduct, it is important to distinguish status-based criminalization from conduct-based criminalization. Status-based criminalization is an effort to make certain acts that are directly related to one's immigration status criminal. Due to federal preemption ${ }^{129}$ and the plenary power of the federal government over immigration law, ${ }^{130}$ federal laws control the domain of criminal immigration offenses. As discussed in more detail below, however, some states have avoided direct criminalization based on one's status and instead have criminalized specific actions taken, out of necessity, by individuals with a certain status, particularly those who are undocumented. ${ }^{131}$ Conduct-based criminalization is based on the conduct itself, regardless of one's status. These distinctions become blurred when laws appear to target conduct, but instead clearly criminalize individuals based on immigration status.

\section{Direct Criminalization}

At present, forms of direct criminalization of contributions are very limited. In theory, the government could directly criminalize a contribution if it chose to criminalize work by noncitizens who lack employment authorization. Currently, the Immigration Reform and Control Act of 1986 (IRCA) ${ }^{132}$ imposes civil penalties for employers who hire or recruit noncitizens who are known to be unauthorized. ${ }^{133}$ Employers that show a pattern and practice of employing unauthorized immigrants may even face criminal penalties. ${ }^{134}$ Yet employees who work without documentation do not face IRCA penalties, unless they affirmatively present fraudulent documents. ${ }^{135}$ Should legislators decide to change the law, it would represent a form of direct criminalization of a contribution, notwithstanding the economic and broader societal contributions that flow from employment. Some jurisdictions have attempted to criminalize the solicitation of work through local

129. See Arizona v. United States, 567 U.S. 387, 416 (2012) (holding that specific sections of Arizona's SB 1070, which sought to criminalize noncitizens who work without authorization and to permit state officers greater authority to arrest noncitizens who may be removable, were preempted by federal law).

130. See generally Fong Yue Ting v. United States, 149 U.S. 698, 728 (1893) (articulating the federal government's broad power over deportation and exclusion of noncitizens).

131. See infra Section III.B.2.

132. 8 U.S.C. $\S \S 1160,1187-1188,1255 a, 1324-1324 b, 1264-1265$ (2012).

133. Id. § $1324 \mathrm{a}(\mathrm{a})(1)-(2)$ (making it unlawful to hire, recruit, or continue to employ a worker without authorization to work in the United States).

134. Id. $\S 1324 \mathrm{a}(\mathrm{f})$.

135. Id. $§ 1324 \mathrm{c}(\mathrm{a})$. 
ordinances, ${ }^{136}$ though such laws are often struck down as unconstitutional on first amendment or federal preemption grounds. ${ }^{137}$ Though few have survived, these laws represent an effort to directly criminalize a sustained everyday contribution.

\section{Indirect Criminalization}

Contributions that are indirectly criminalized or that result in certain immigration consequences are much more common and can be just as devastating as direct criminalization. Unlike direct criminalization, indirect forms are sometimes less apparent, particularly to those individuals who may be affected, and are therefore more insidious. This section offers examples of the indirect criminalization of contributions.

Some of the sustained contributions described above are indirectly criminalized at the federal and/or state levels. Status-based criminalization related to workplace contributions is one such example. While federal law imposes sanctions only against the employer for hiring unauthorized workers, ${ }^{138}$ workers are nonetheless targeted for the use of false documents. One notorious example is the Postville raids that occurred in 2008. As detailed by Ingrid Eagly, the enforcement operation at the meatpacking plant in Iowa led to one of the largest immigration criminal prosecutions in history. ${ }^{139}$ Facing threats of federal prosecution for aggravated identity theft, most workers "pleaded guilty to [the] false use of a document as evidence of authorized employment." 140 Eagly argues that the Postville raids are "emblematic of the blending of our criminal and immigration systems." $"$ These raids also illustrate one

136. See generally Kristina M. Campbell, The High Cost of Free Speech: Anti-Solicitation Ordinances, Day Laborers, and the Impact of "Backdoor" Local Immigration Regulations, 25 GEO. IMM. L.J. 1, 4-20 (2010) (describing numerous anti-solicitation ordinances targeted at immigrant day laborers, and related litigation responses); Karla Mari McKanders, Welcome to Hazleton! "Illegal" Immigrants Beware: Local Immigration Ordinances and What the Federal Government Must Do About It, 39 LOY. U. CHI. L.J. 1, 6-8 (2007) (detailing the rise of immigration-related local ordinances, particularly those regulating employment, in 2006 and 2007).

137. See State v. Garcia, 401 P.3d 588, 599 (Kan. 2017) ("States are prohibited from using the I9 and any information contained within the $I-9$ as the bases for a state law identity theft prosecution of an alien who uses another's Social Security information in an I-9.") (emphasis in original) petition for cert. docketed, Kansas v. Ramiro-Garcia (Dec. 11, 2017) (No. 17-834); Centro de la Comunidad Hispana de Locust Valley v. Town of Oyster Bay, 128 F. Supp. 3d 597, 620-21 (E.D.N.Y. 2015) (holding that a local ordinance that targeted day laborers soliciting work was unconstitutional under the First Amendment).

138. 8 U.S.C. $\S 1324 a(a)(1)-(2)$.

139. Ingrid V. Eagly, Prosecuting Immigration, 104 Nw. U. L. REV. 1281, 1301 (2010).

140. Id. at 1302 .

141. Id. at 1304 . 
example of indirect federal criminalization of an everyday contribution, specifically contributions to the labor force, by targeting the predicate act of providing false documents.

Similarly, some states have used identity theft laws as a way to prosecute noncitizens who use false identities to obtain employment. ${ }^{142}$ As noted by Jennifer Chacón, Arizona's identity theft statute, which in effect targets unauthorized workers, "does not require theft of an actual identity, [and] can be deployed as a means of prosecuting noncitizens who have used false identities to obtain employment in cases where there is no loss to anyone as a result of the use of that identity." 143 The Ninth Circuit Court of Appeals ruled that the statute was not federally preempted in its entirety. ${ }^{144}$ The district court later issued an order enjoining the Maricopa County Sheriff from using certain documents, such as a Form I-9, for the purpose of prosecuting identity theft. ${ }^{145}$

Another example of indirect criminalization seen nationwide is the enforcement of driving infractions against immigrant communities, specifically driving without a license. For many people, noncitizens and citizens alike, the ability to drive is a necessary predicate to employment, interaction with the community, and support for one's family. Yet, only a small number of states have enacted laws that make it possible to obtain a

142. See Leticia M. Saucedo, The Making of the "Wrongfully" Documented Worker, 93 N.C. L. Rev. 1505, 1530 (2015) ("Over the past decade or so, states have enacted or amended identity theft statutes to criminalize the false use of Social Security numbers or other identifying information for employment. Such laws are ostensibly and sometimes explicitly aimed at reserving jobs for the native-born, majority-white populations in those states.").

143. Chacón, supra note 40, at 138 . The statute states:

A person commits taking the identity of another person or entity if the person knowingly takes, purchases, manufactures, records, possesses or uses any personal identifying information or entity identifying information of another person or entity, including a real or fictitious person or entity, without the consent of that other person or entity, with the intent to obtain or use the other person's or entity's identity for any unlawful purpose or to cause loss to a person or entity whether or not the person or entity actually suffers any economic loss as a result of the offense, or with the intent to obtain or continue employment.

ARIZ. ReV. StAT. ANN. § 13-2008(A) (West 2018).

144. See Puente Arizona v. Arpaio, 821 F.3d 1098, 1110 (9th Cir. 2016) (reversing the district court's grant of the preliminary injunction after concluding that Arizona's employment-related identity theft laws were not preempted in all applications).

145. Puente Arizona v. Arpaio, No. CV-14-01356-PHX-DGC, 2017 WL 1133012, at*17 (D. Ariz. Mar. 27, 2017) (holding that the defendants' use of the I-9 forms for state identity theft prosecutions was preempted under federal law and granting the requested preliminary injunction such that the Maricopa County Sheriff could no longer rely on the Form I-9 for purposes of investigating or prosecuting violations of the state identity theft statute); see also I-9, Employment Eligibility Verification, U.S. IMMIGR. \& CUSTOMS ENF'T, https://www.uscis.gov/i-9 (last updated July 17, 2017) (describing information pertaining to the I-9 form). 
driver's license regardless of immigration status. ${ }^{146}$ The majority of states require both proof of identity and legal presence in the United States. ${ }^{147} \mathrm{In}$ Virginia, for example, the specific categories of documents required to show legal presence create barriers to obtain a driver's license for even noncitizens who have received immigration relief. ${ }^{148}$ Thus, for undocumented immigrants and other noncitizens, driving with a license is not a choice in their state; their status makes obtaining a license impossible, rendering them vulnerable to criminal charges. Not only does the criminalization of this act make noncitizens vulnerable to increased interactions with the criminal justice system, it also makes their ability to achieve some of the contributions discussed herein nearly impossible.

While these examples of indirect criminalization are alarming, this pattern has been apparent for well over a decade. ${ }^{149}$ What has expanded significantly under the current administration is the indirect criminalization of the second category of contributions - those that support government functions. For example, a memorandum issued by John Kelly, then-Secretary of the Department of Homeland Security (DHS), states that the administration will prioritize specific ORR sponsors for removal and possible prosecution. ${ }^{150}$ Not only does this directly

146. The National Immigration Law Center (NILC) compiled a list of the fourteen jurisdictions that permitted state residents to get a driver's license regardless of immigration status. NAT'L Immigration Law Ctr., State LAws Providing ACCess to Driver's LiCenses or CARDS, REGARDLESS OF IMMIGRATION STATUS (May 2017), https:/www.nilc.org/wp-content/uplo ads/2015/11/drivers-license-access-table.pdf. Indeed, some states even prohibit giving driver's licenses to those who have some form of legal status. Id.

147. See Adam Hunter \& Angelo Mathay, Driver's Licenses for Unauthorized Immigrants: 2016 Highlights, PEW CHARITABLE TR. (Nov. 22, 2016), http://www.pewtrusts.org/en/ research-andanalysis/analysis/2016/11/22/drivers-licenses-for-unauthorized-immigrants-2016-highlights (finding that as of November 2016, only twelve states and the District of Columbia allow unauthorized immigrants to obtain a driver's license or card).

148. See Obtaining a Virginia Driver's License or Identification (ID) Card, VA. DEP'T MOTOR VEHICLES (Nov. 16, 2017), https://www.dmv.virginia.gov/webdoc/pdf/dmv141.pdf (listing the accepted documents to show legal presence in the United States).

149. See, e.g., Annie Lai, Confronting Proxy Criminalization, 92 DENV. U. L. REV. 879, 889-92 (2015) (noting that restrictions on immigrants' access to driver's licenses can be traced back to the 1990s).

150. Memorandum from John Kelly, Sec'y of Homeland Sec. to Kevin McAleenan, Acting Comm'r, U.S. Customs \& Border Prot., Thomas D. Homan, Acting Dir., U.S. Immigration \& Customs Enf't, Lori Scialabba, Acting Dir., U.S. Citizenship \& Immigration Servs., Joseph B. Maher, Acting Gen. Counsel, Dimple Shah, Acting Assistant Sec'y for Int'l Affairs, Chip Fulghum, Acting Undersecretary for Mgmt., on Implementing the President's Border Security and Immigration Enforcement Improvements Policies 11 (Feb. 20, 2017), https://www.dhs.go v/sites/default/files/publications/17_0220_S1_Implementing-the-Presidents-Border-Security-Immig ration-Enforcement-Improvement-Policies.pdf ("Although the Department's personnel must process unaccompanied alien children pursuant to the requirements described above, we have an obligation to ensure that those who conspire to violate our immigration laws do not do so with impunityparticularly in light of the unique vulnerabilities of alien children who are smuggled or trafficked into 
conflict with ORR guidance, ${ }^{151}$ it criminalizes a specific category of sponsors - undocumented parents. On the surface, criminalization of ORR sponsors appears to be conduct-based criminalization; according to the DHS, these sponsors paid someone to bring their children to the United States. ${ }^{152}$ These caretakers, however, would not be subjected to scrutiny if they were not made to register with ORR, resulting in the disclosure of their status to other government agencies. Thus, while this policy appears to be based on one's conduct, the capacity to target these specific caretakers is based on their immigration status.

Furthermore, undocumented parents or relatives living in the United States typically have no lawful pathway to bring their children to the country. ${ }^{153}$ Consequently, because of the limitations that accompany their own status, undocumented parents are forced to find other ways to reunite with their children in the United States. ${ }^{154}$ The February 2017 memorandum does not appear to be an empty threat, as various news sources have reported arrests of ORR sponsors. ${ }^{155}$ These heightened threats

the United States. . . A Accordingly, the Director of ICE and Commissioner of CBP shall ensure the proper enforcement of our immigration laws against any individual who - directly or indirectlyfacilitates the illegal smuggling or trafficking of an alien child to the United States.") [hereinafter Kelly Memo].

151. Consistent with the Flores Stipulated Settlement, ORR releases unaccompanied minors to sponsors in order of preference:

parent; legal guardian; an adult relative (brother, sister, aunt, uncle, grandparent or first cousin); an adult individual or entity designated by the parent or legal guardian (through a signed declaration or other document that ORR determines is sufficient to establish the signatory's parental/guardian relationship); a licensed program willing to accept legal custody; or an adult individual or entity seeking custody when it appears that there is no other likely alternative to long term ORR care and custody.

Children Entering the United States Unaccompanied: Safe and Timely Release from ORR Care, supra note 121 .

152. See Kelly Memo, supra note 150, at 10 ("Most of these minors are from El Salvador, Honduras, and Guatemala, many of whom travel overland to the southern border with the assistance of a smuggler who is paid several thousand dollars by one or both parents, who reside illegally in the United States.").

153. See Green Card Eligibility Categories, U.S. CitizenshiP \& ImMigr. Servs., https://www.uscis.gov/greencard/eligibility-categories (last visited Feb. 27, 2018) (specifying the limited pathways that one can receive permanent residence via a family member).

154. See Nick Miroff, To Curb Illegal Border Crossings, Trump Administration Weighs New Measures Targeting Families, WASH. POST (Dec. 21, 2017), https://www.washingt onpost.com/world/national-security/to-curb-illegal-border-crossings-trump-administration-weighsnew-measures-targeting-families/2017/12/21/19300dc2-e66c-11e7-9ec2-

518810e7d44d_story.html?utm_term=.b3d9dd61feae. Indeed, with threats to separate parents from their children at the border, parents may choose to enter separately from their children. Id.

155. See e.g., John Burnett, ICE Has Arrested More Than 400 in Operation Targeting Parents Who Pay Smugglers, NPR (Aug. 18, 2017, 4:31 PM), http://www.npr.org/2017/08 /18/544523231/arrests-of-undocumented-parents-sparks-debate-between-federal-officials-and-immi; Caitlin Dickerson, Trump Administration Targets Parents in New Immigration Crackdown, N.Y. TIMES (July 1, 2017), https://www.nytimes.com/2017/07/01/us/trump-arrest-undocumented- 
against undocumented sponsors significantly reduce any incentive to become a sponsor. With only negative outcomes imposed by the state for sponsorship, undocumented sponsors may be reluctant to step forward, and unaccompanied minors may be placed in less secure settings. ${ }^{156}$

At the state level, workers who report and seek compensation for workplace injuries, and thus indirectly support government efforts to promote workplace safety, also face potential criminalization. ProPublica and National Public Radio (NPR) reported that undocumented immigrants in Florida who filed for workers' compensation were then targeted for prosecution for filing a claim using false identification. ${ }^{157}$ Some were not aware that a false identification number had been forwarded from the employer to the insurance company. ${ }^{158}$ By covering medical expenses, workers' compensation certainly benefits the worker who reports the injury; however, filing a claim also serves to document a workplace safety issue, as the injury may have resulted from a dangerous condition in the workplace. In this regard, reporting a workplace safety issue not only benefits the worker-complainant but also the other workers who may face the same dangers at that workplace. Yet instead of being encouraged to report, some undocumented workers face criminal charges for filing for workers' compensation. Notably, the reporters found that ninety-nine percent of the workers arrested under the statute were Latino immigrants working with false documents. ${ }^{159}$ These statistics illustrate that this form of criminalization is status-based. Like sponsors of unaccompanied minors, a likely effect of the prosecutions will be to chill noncitizen workers from filing similar claims in the future, thus weakening the overall integrity of the regulatory apparatus. Rational choice theory instructs us that workers should have some incentives to file claims, and they must feel that they are ultimately better off for engaging with the government. ${ }^{160}$

\footnotetext{
immigrants.html?mcubz=1; Franco Ordoñez, Trump Administration Targets Parents Who Paid to Smuggle Children into U.S., MiAMI HERALD (June 29, 2017, 2:38 PM), http://www.miamiherald. com/latest-news/article158953664.html.

156. Cf. Molly Hennesy-Fiske, Young Immigrants Placed in Sponsor Homes are at Risk of Abuse, Experts Say, L.A. TIMES (Aug. 18, 2015, 4:00 AM), http://beta.latimes.com/nation/la-na-immigrantsponsors-20150818-story.html (reporting on the lack of oversight in placing unaccompanied minors with sponsors living in the United States).

157. Michael Grabell \& Howard Berkes, They Got Hurt at Work. Then They Got Deported., ProPublica (Aug. 16, 2017, 5:00 AM), https://www.propublica.org/article/they-got-hurt-at-workthen-they-got-deported.

158. Id.

159. Id.

160. See supra notes $85-88$ and accompanying text.
} 


\section{Separate Criminal Activity}

The final category of criminalization includes separate criminal activity that is not related to a specific contribution, but it may operate to override the positive impact of the noncitizens' contributions. Every day, immigrants who are facing the prospect of removal find themselves before decision-makers who scrutinize prior criminal activity. ${ }^{161}$ Given the insidious associations made between unauthorized migration and criminality, even relatively minor criminal conduct can outweigh significant connections and contributions to the United States. For example, in the context of applications for DACA — which confers simply a reprieve from removal, and not an affirmative status - applicants with certain misdemeanor convictions are ineligible to receive the benefit. ${ }^{162}$

Even contributions that support the government are dampened by unrelated allegations of criminality, especially in the current political climate. In the past, applicants who were able to link the criminal conduct to the underlying victimization were able to move forward with their $U$ or T visa applications. ${ }^{163}$ Anecdotally, now however, more applicants for $\mathrm{U}$ or T visas who have a criminal history fear being reported to ICE due to increased collaboration between immigration enforcement and local law enforcement. ${ }^{164}$ Consequently, a contribution that assists an important government function-investigation and prosecution of crimes-and provides a path to legal status, has become tainted, thus discouraging immigrant survivors of violence from fulfilling the very purpose of the program. ${ }^{165}$

Noncitizens who have served in the military are also at risk for deportation due to criminal activity. The contributions of veterans are overlooked in an immigration system that ignores the context for criminal conduct and instead categorically denies relief based on specific criminal convictions. $^{166}$ As a result of their service, veterans may suffer from

161. See Alina Das, The Immigration Penalties of Criminal Convictions: Resurrecting Categorical Analysis in Immigration Law, 86 N.Y.U. L. REV. 1669, 1672-73 (2011) (describing how analysis of criminal convictions has become central to administrative immigration decisions).

162. See Rathod, supra note 30, at 174-76 (describing the criminal bars to eligibility for DACA, including having a "significant misdemeanor" conviction).

163. See Elizabeth Keyes, Beyond Saints and Sinners: Discretion and the Need for New Narratives in the U.S. Immigration System, 26 GEO. IMMIGR. L.J. 207, 228-31 (2012) (explaining the availability of waivers for applicants for U visas and VAWA cancellation).

164. See e.g., Nora Caplan-Bricker, "I Wish I'd Never Called the Police," Slate (Mar. 19, 2017, 8:12 PM), http://www.slate.com/articles/news_and_politics/cover_story/2017/03/u_visas_gav e_a_safe_path_to_citizenship_to_victims_of_abuse_under_trump.html.

165. See supra notes $92-97$ and accompanying text.

166. See 8 U.S.C. $\S 1227(a)(2)(A)$ (2012) (providing the categories of deportable offenses based 
various mental health conditions when returning from war, such as posttraumatic stress disorder, drug addiction, or others, which may lead them to commit crimes. ${ }^{167}$ The immigration laws afford little discretionary leeway for veterans with certain types of criminal convictions, leading to removal proceedings and even deportations. ${ }^{168}$ Although the government does not maintain a record of the number of deported veterans, over 200 cases have been documented, and many of them were deported due to drug-related convictions. ${ }^{169}$

The ever-expanding forms of criminalization of both sustained economic, social, and cultural contributions, and sustained and/or substantial contributions that support government functions leads to the expulsion of noncitizens who would otherwise have positive equities in their favor. Criminalization also impedes one's ability to make more substantive contributions. Noncitizens become so afraid they cannot contribute in ways that will later be rewarded, as demonstrated by survivors of crime who refuse to report crimes committed against them for fear of interacting with law enforcement. ${ }^{170}$ Criminalization prevents community engagement and undermines potentially positive equities that serve the broader community and, in some cases, support the government.

The theoretical framework articulated in Section II provides justification for treating contributions as positive equities and minimizing the weight afforded to certain criminal acts. ${ }^{171}$ Under the modified theory of jus nexi, or jus nexi et contributionum, both everyday contributions and contributions that support government functions should be weighed as positive equities and evidence of one's connection to society. The sections

on criminal conduct).

167. Hartsfield, supra note 112, at 850.

168. Immigrant Vet Awaits Judge's Deportation Ruling After Drug Conviction, Fox News (Mar. 7, 2017), http://www.foxnews.com/us/2017/03/07/immigrant-vet-awaits-judges-deportation-rulingafter-drug-conviction.html. Jose Padilla, whose ineffective assistance of counsel claim was appealed to the Supreme Court in Padilla v. Kentucky, is another example. 559 U.S. 356, 359, 374 (2010). Padilla served as a member of the U.S. Armed Forces in Vietnam and later faced deportation after pleading guilty to transporting a large amount of marijuana. Id. at 359 .

169. Miriam Jordan, 15 Years After Deportation, Marine Wins Right to Come Back to U.S., N.Y. TiMES (Dec. 18, 2017), https://www.nytimes.com/2017/12/18/us/veteran-deported-pardoned.html ?hp\&action=click\&pgtype $=$ Homepage $\&$ clickSource $=$ story-heading\&module=second-columnregion\&region=top-news\&WT.nav=top-news\&_r=0\&mtrref=1.facebook.com; Translation - From $A$ Distance, RADIO AMBULANTE (Nov. 28, 2017), http://radioambulante.org/en/audio-en/ translation/translation-from-a-distance.

170. Jennifer Medina, Too Scared to Report Sexual Abuse. The Fear: Deportation, N.Y. TIMES (Apr. 30, 2017), https://www.nytimes.com/2017/04/30/us/immigrants-deportation-sexual-abuse.html; James Queally, Fearing Deportation, Many Domestic Violence Victims are Steering Clear of Police and Courts, L.A. TIMES (Oct. 9, 2017, 5:00 AM), http://www.latimes.com/local/lanow/la-me-lnundocumented-crime-reporting-20171009-story.html.

171. See supra notes 58-63 and accompanying text. 
above outline some of the contours of these specific contributions, including the duration and amount of benefit to others.

Equity theory and rational choice theory offer a theoretical justification for providing a path to membership based on substantial contributions that support a government function. While some of these contributions are recognized under immigration law, such as the $\mathrm{U}$ or $\mathrm{T}$ visa, the new priorities to target noncitizens with any criminal interaction threatens $\mathrm{U}$ or $\mathrm{T}$ visa applicants with deportation based on separate criminal conduct, thus discouraging noncitizens from coming forward to report their crimes. ${ }^{172}$ Despite the purpose of these visa programs, more noncitizens may fear interacting with local law enforcement, resulting in fewer reports of crime. ${ }^{173}$ In their simplest forms, equity and rational choice theory justify rewarding such contributions that support law enforcement functions, so as to maintain the incentive to cooperate. Specifically, for one's cooperation in an investigation, the applicant should receive a work permit and a path to lawful status.

\section{Weighing both Contributions and Criminal Conduct}

Scholars and advocates have distinct views on how to assess criminal history in weighing equities in the immigration context. Some argue that when a person has served his or her sentence, he or she should not face further consequences, especially one as dire as deportation. ${ }^{174}$ The Supreme Court in Padilla v. Kentucky recognized the severity of this collateral consequence when it held that a criminal defense attorney's failure to advise a client about the immigration consequences of a criminal conviction can form the basis of an ineffective assistance of counsel claim. ${ }^{175}$ When one also considers the enormous racial disparities in the criminal justice system, the use of criminality as a proxy for desirability is especially problematic. Not only are the racial implications of criminalization alarming, noncitizens face a form of double punishment when their conviction possibly leads to deportation. ${ }^{176}$

172. See Enhancing Public Safety in the Interior of the United States, Exec. Order No. 13768, 82 Fed. Reg. 8799 (Jan. 25, 2017); supra notes 161, 167, and accompanying text.

173. Rathod, supra note 30, at 174-76.

174. E.g., Maureen Sweeney \& Hillary Scholten, Penalty and Proportionality in Deportation for Crimes, 31 St. LouIs U. L.J. 11, 36-40 (2011) (arguing that Eighth Amendment jurisprudence should inform a proportionality analysis in deportation based on crime and that categories of criminal deportations would likely fail to meet this standard).

175. 559 U.S. 356, 374-375 (2011).

176. See Banks, supra note 12, at 1669 (arguing that post-entry crime-based deportation is punitive). 
Others, including Obama administration officials, have attempted to draw the line at noncitizens who commit more serious crimes. During his second term, President Obama emphasized in a speech, "Felons, not families. Criminals, not children." 177 The reality of deportation under that administration, however, told a very different story. In practice, those targeted under federal programs, such as $287(\mathrm{~g})$ of the Immigration and Nationality Act (INA) and the Secure Communities program that allowed local law enforcement to assist federal immigration enforcement, were low-level offenders. ${ }^{178}$ While the Obama administration purported to follow a set of priorities for enforcement, particularly as it related to noncitizens with limited or no criminal history, the current administration has eliminated any priority-setting in this regard and has instead targeted any noncitizen who has contact with the criminal justice system. ${ }^{179}$ The Trump administration even created an office of victim assistance for crimes committed by immigrants, called Victims of Immigration Crime Engagement (VOICE). ${ }^{180}$ The establishment of this office under the authority of ICE suggests that crimes committed by noncitizens are somehow more extensive or concerning than those committed by citizens. As stated on the ICE website, "ICE wants to ensure those victimized by criminal aliens feel heard, seen and supported." ${ }^{181}$ Such a program only underscores the perceived severity of crimes committed by noncitizens.

Given the rapid convergence of criminal and immigration law, it is unlikely that criminal conduct, as a negative factor, will disappear altogether. Indeed, in the current immigration system, criminality seems to be the ultimate marker of undesirability. Consistent with the focus of

177. President Barack Obama, Remarks by the President in Address to the Nation on Immigration, (Nov. 20, 2014), https://obamawhitehouse.archives.gov/the-press-office/2014/11/20/remarkspresident-address-nation-immigration ("Mass amnesty would be unfair. Mass deportation would be both impossible and contrary to our character. What I'm describing is accountability-a commonsense, middle-ground approach: If you meet the criteria, you can come out of the shadows and get right with the law. If you're a criminal, you'll be deported. If you plan to enter the U.S. illegally, your chances of getting caught and sent back just went up.").

178. Randy Capps, et al., Delegation and Divergence: A Study of 287(G) State and LOCAL IMMigRATION ENFORCEMENT 19-21 (Migration Policy Inst., Jan. 2011), https://www.migrationpolicy.org/research/delegation-and-divergence-287g-state-and-localimmigration-enforcement (finding that in $287 \mathrm{~g}$ ) jurisdictions that placed immigration detainers on any noncitizen that the majority of detainees had low-level offenses or traffic violations); see also supra note 14 and accompanying text.

179. Enhancing Public Safety in the Interior of the United States, Exec. Order No. 13768, 82 Fed. Reg. 8799 (Jan. 25, 2017) (stating that the enforcement priorities include noncitizens who have been convicted of any criminal offense, who have been charged with any criminal offense, or who have committed acts that constitute a chargeable offense).

180. Victims of Immigration Crime Engagement (VOICE) Office, U.S. IMMIGR. \& CUSTOMS ENF'T, https://www.ice.gov/voice (last updated Sept. 18, 2017).

181. Id. 
this article, however, one potential option to balance the equities in a more just manner is to consider the context of both the contributions and the conviction. Criminal conduct that results from conditions created by one's significant contribution, such as the case of veterans who commit crimes as a result of post-traumatic stress disorder, should be viewed in that context and granted little, if any weight against the noncitizen. Temporal considerations - namely, the amount of time that has lapsed since the criminal activity occurred-is another contextual factor. Along these lines, some scholars have called for a statute of limitations on deportations triggered by old criminal convictions. ${ }^{182}$

Another possible dividing marker is status-based versus conductbased criminalization. Many of the contributions that have been criminalized directly or indirectly are based solely on one's status, rather than based on conduct independent of one's status. Convictions that are merely status-based, such as driving without a license in a state that does not permit an undocumented person to obtain a license, should not be given any weight against the noncitizen. Even at a basic level, entry across the border is not criminal conduct; rather, it is regulatory and based on one's status. ${ }^{183}$ If the executive and legislative branches continue to use criminal conduct as a marker for undesirability, which is concerning for the reasons discussed above, they should at least consider only behavior that is separate from one's immigration status.

Regarding conduct-based criminalization, yet another approach, as mentioned, is to remove criminality as a negative equity altogether. This is unlikely to happen in the current political climate, given the expanded efforts to target any noncitizen who interacts with the criminal justice system. ${ }^{184}$ An alternative theory is to adopt proportionality in immigration enforcement, as suggested by other immigration scholars. ${ }^{185}$ Borrowing from guidance on punitive damages in civil litigation, as recommended by Angela Banks, immigration adjudicators may examine three guideposts to evaluate the proportionality of deportation grounds: (1) consideration of the enormity of the deportable offense; (2) individualized assessment of the facts and context giving rise to the criminal conviction; and (3)

182. See, e.g., Kim, supra note 45 , at 535-37.

183. See 8 U.S.C. $\$ 1182(a)(6)(A)(i)$ (2012) (treating entry without inspection as a ground of inadmissibility that can lead to removal proceedings); see also id. $\S 1325$ (penalizing any noncitizen who enters without examination or inspection by an immigration officer with either a fine or imprisonment up to six months for the first offense and up to two years for subsequent offenses).

184. See supra notes $166-70$ and accompanying text.

185. See, e.g., Jason A. Cade, Judging Immigration Equity: Deportation and Proportionality in the Supreme Court, 50 U.C. DAVIS L. REV. 1029 (2017) (discussing the Supreme Court's proportionality-influenced jurisprudence). 
availability of other criminal or civil penalties as an indicator of excessiveness. ${ }^{186}$ For this final element, the concept of double punishment would still be relevant, as noncitizens with criminal convictions already served their sentence when placed in removal proceedings. ${ }^{187}$

Ultimately, this article suggests that a broad swath of contributions should be given favorable weight in discretionary enforcement decisions. It highlights how criminalization can hinder some forms of contributions and examines how specific contributions can actually lead to criminalization. It demonstrates that criminalization in immigration law has become an ever-expanding black hole that needs some limits. Immigration law must not just be controlled by more procedural protections, but by reassessing the equities examined by immigration judges and other government adjudicators, and by distinguishing between status and conduct-based criminalization. When applying these interpretive tools, the contributions described in this article should be given significant, positive weight in the context of enforcement decisions. Furthermore, contributions that support government functions either directly or indirectly should be given greater weight by the state. While other contributions are no less significant, equity theory more clearly supports this approach, as noncitizens contribute to state functions and the state reciprocates by offering the right to remain.

\section{LIMITATIONS \& CONCLUSION}

The approach suggested in this article - of weighing contributions made by noncitizens and critically analyzing forms of contributions-is not without its limitations. Contributions can happen in a myriad of ways, and some are less easily measured or difficult to define. This article attempts to broaden what should be considered in weighing positive equities in the context of enforcement decisions. While economic contributions are significant, they should not be the singular focus for relief. Even so, the task of drawing the line at certain types of contributions and weighing one against another is difficult. Does a noncitizen who has been active in the community and consistently supports her family in the United States have more contributions in her favor than, for example, the beloved immigrant subway performer who has no dependents? While we suggest some basic guidelines for duration and who benefits from the contribution, this article does not clearly define this line. The hope is that it expands the types of contributions that may

186. Banks, supra note 12 , at 1677-78.

187. Keyes, supra note 161, at 228-31 and accompanying text. 
be taken into account in determining who deserves to remain in the country.

One pitfall that an emphasis on contributions seeks to avoid is the "good" versus "bad" immigrant narrative. This narrative is now entrenched in the way we speak about immigration reform, both under the current and prior administrations. The purpose of this article is to blur this line, as such distinctions are rarely straightforward. Noncitizens with criminal histories should not be automatically excluded from various forms of immigration relief. The harsh penalties in the U.S. civil immigration system for noncitizens with convictions are overly punitive. As noted above, such a narrative fails to recognize racial injustice and unfairness inherent in the U.S. criminal justice system. The incorporation of contributions in this framework should not serve to reinforce this divide between "good" and "bad" immigrants. Rather, the purpose is to emphasize that equities should fall on a spectrum and to suggest the types of contributions that should be considered.

In some cases, the criminalization of contributions is already so deeply entrenched that immigrants do not perform specific contributions out of fear for its consequences. For example, noncitizens may choose not to engage in the community, if it involves driving without a license to participate. While this article suggests an expansive range of contributions to consider, we also recognize that the criminalization of immigrant communities, especially in the current political climate, is so intense that many noncitizens may choose not to make certain contributions. This is an inherent limitation of a contributions-focused approach.

Furthermore, the contributions framework overlaps somewhat with a theory of earned citizenship, as detailed in the work of Shachar and others. While this theory has positive aspects, there are nonetheless critiques of this framework. This theory assumes that noncitizens, especially those who are entered without authorization, start with some moral deficit. ${ }^{188}$ As Muneer Ahmad notes, earned citizenship heavily emphasizes economic performance in its calculus. ${ }^{189}$ Ahmad argues that an emphasis on earned citizenship overlooks the structural causes motivating undocumented immigrants and the marginalization of these immigrants. ${ }^{190}$ The theory of examining contributions also faces some of the challenges of earned citizenship, specifically that noncitizens have to prove their worth to remain in the United States. However, our approach seeks to remove the

\footnotetext{
188. Ahmad, supra note 57, at 298 (arguing that earned citizenship reinforces the "immigrant-ascriminal narrative" promoted by immigration restrictionists).

189. Id. at 279 .

190. Id. at 264 .
} 
"original sin" of undocumented status and to emphasize the contributions made in the United States, rather than the circumstances that led to one's entry.

Despite these limitations, this article offers another theory for equitable consideration in immigration law-contributions made by noncitizens. We offer a broad range of examples that fall into two categories: (1) sustained economic, social, or cultural contributions to families, communities, or society at large, but that do not affirmatively or indirectly support government functions; and (2) substantial and/or sustained contributions that support government function, either directly or indirectly. Using theoretical underpinnings, including equity theory, jus nexi principles, and rational choice theory, we provide justifications for considering these specific contributions in assessing noncitizens' right to remain in the United States. ${ }^{191}$ Additionally, the article details the impact of criminalization of immigration law on weighing contributions and even noncitizens' ability to make specific contributions. ${ }^{192}$ The three categories of direct and indirect criminalization and separate criminal conduct demonstrate the enormity of the obstacle created by the use of criminality as a negative equity in enforcement decisions. Even so, we offer that status-based criminalization, which results merely from undocumented status, should not be given significant, if any, weight in evaluating one's right to remain. Consideration of a broader range of contributions, in addition to a more context-specific understanding of criminal conduct, will instill greater equity and fairness into the U.S. immigration system.

191. Supra notes 159-62 and accompanying text.

192. Supra Section III.B. 